\title{
Quantitative mapping and statistical evaluation of fracture minerals in the granitic bedrock at Forsmark, Sweden
}

\author{
Martin Löfgren $^{1} \cdot$ Magnus Sidborn $^{2}$
}

Received: 16 June 2015 / Accepted: 29 February 2016 / Published online: 9 March 2016

(C) The Author(s) 2016. This article is published with open access at Springerlink.com

\begin{abstract}
This article provides quantitative data on occurrences and amounts of fracture minerals that coat discrete fractures in granitic rock at the Forsmark site in Sweden. The data are useful for retardation modelling of radionuclide and other contaminants, and for groundwater composition calculations. In a unique campaign, 2071 open fractures in groundwater conducting rock have been mapped with respect to chlorite, calcite, and pyrite. In total $767 \mathrm{~m}$ of drill core has been studied from very shallow rock down to $\sim 1000 \mathrm{~m}$ depth. The occurrences of fracture minerals, their thicknesses, and their fractions of surface coverage have been recorded for up to eight layers for each fracture. Detection limits are, for each layer, $0.1 \mathrm{~mm}$ for the thickness and $1 \%$ for the surface coverage, except for pyrite crystals where surface coverages down to $0.01 \%$ are detectable. The abundance of data has permitted statistical treatment, using parametric and non-parametric methods. Parametric fittings have been made to log-normal, truncated log-normal, and beta distributions. Chlorite, calcite, and pyrite were found in $57 \%, 52 \%$, and $10 \%$ of all mapped fractures, respectively. The fracture mineral thickness was $0.1 \mathrm{~mm}$ for calcite, $0.2 \mathrm{~mm}$ for chlorite, and $2 \mu \mathrm{m}$ for pyrite, as averaged over the fracture surface area. For $50 \%$ and $99 \%$ of all fractures the total fracture coating thickness was less than $0.1 \mathrm{~mm}$ and $1 \mathrm{~mm}$, respectively, which is important for diffusion resistance estimates. Average surface coverages
\end{abstract}

Editorial handling: L. Nasdala

Martin Löfgren

martin.lofgren@niressa.se

1 Niressa AB, Östra Fyrby Tomtstugan 1, 64040 Stora Sundby, Sweden

2 Kemakta, Box 12655, 11293 Stockholm, Sweden were $18 \%$ for calcite, $38 \%$ for chlorite, and $0.5 \%$ for pyrite. These data may be used for calculating the reaction capacity of flow paths.

\section{Introduction}

\section{Background}

The main purpose of this article is to present data on fracture mineral abundances and thicknesses in underground fractured crystalline rock, such as granodiorite and granite. The work was initiated to serve solute and contaminant transport modelling. Hence, the background and a few other sections are written from that perspective.

In fractured crystalline rock, the hydraulic conductivity of the rock matrix is very small and a great majority of the flowing groundwater is confined to single fractures and fracture zones. In many cases, the fracture surfaces are coated by fracture minerals, such as calcite and chlorite. These fracture minerals provide the first reactive surfaces to groundwater constituents and contaminants dissolved in the flowing water. This means that fracture minerals may be of importance when estimating 1) solute/fracture mineral reactions; 2) solute sorption and immobilisation on fracture minerals; and 3) diffusive transport through fracture minerals, providing access to the underlying rock matrix. Fracture minerals are of particular importance in case of a pulse release of contaminants to a system with short flow paths and high water flows. A typical example of this would be short-term field tests in underground rock systems, for example dipole tracer tests along flow paths of limited length, where only the rock material in immediate contact with the flow path serves as reaction capacity (Zhou et al. 2007). 
Contaminant transport in fractured crystalline rock has been studied for decades within the field of radionuclide transport and retardation (e.g. Birgersson and Neretnieks 1990; Miller et al. 1994; Ota et al. 2003; Andersson et al. 2004). This is mainly done to assess the risk of radionuclides escaping from geological disposals for radioactive waste, into the geosphere, and further on to the biosphere (SKB 2011; POSIVA 2012). Long-range transport of dissolved radionuclides is assumed to occur via groundwater flow in discrete fractures (RETROCK 2005). The most common retardation processes incorporated in models of solute transport are linear sorption to the fracture surfaces; diffusion through the fracture minerals and into the microporous system of the underlying rock matrix; and linear sorption on internal mineral surfaces of the rock matrix. These processes are often parameterised by the surface related sorption partitioning coefficient $K_{a}(\mathrm{~m})$; the effective diffusivity $D_{e}\left(\mathrm{~m}^{2} / \mathrm{s}\right)$; the volumetric sorption partitioning coefficient $K_{d}\left(\mathrm{~m}^{3} / \mathrm{kg}\right)$; and penetration depth $L$ (m), e.g. (Neretnieks 1980; Wels and Smith 1994). There are also attempts to describe retardation by way of cation exchange, surface complexation models, precipitation, co-precipitation, etc. (RETROCK 2005) that to a varying extent require input data relating to the occurrences and amounts of specific mineral phases.

If using the surface related sorption $\left(K_{a}\right)$ approach, and if knowing the individual sorption properties of a set of fracture minerals from laboratory measurements, one needs to know the fraction of the fracture surface that the different minerals cover. This information should be valid for the entire flow path, even though it may be flow-path averaged. If a fracture mineral has a very low effective diffusivity, and thus hinders solutes from reaching the underlying rock matrix, one need to know the fraction of the surface area that it covers, as well as the fracture mineral thickness. It is often assumed, and on occasions demonstrated, that fracture minerals and the altered rock adjacent to hydraulically conductive fractures have a higher effective diffusivity than the undisturbed rock matrix (e.g. Siitari-Kauppi et al. 2003; Widestrand et al. 2007). However, this assumption needs to be strengthened for the fractures of low transmissivity in rock volumes outside larger deformation zones, which are of primary importance for radionuclide retardation in geological disposals for spent nuclear fuel in crystalline rock. Such disposals are by design placed in sparsely fractured rock volumes at a respect distance to large deformation zones. As there is a hydrodynamic control of retention (RETROCK 2005), most retention will occur in flow paths in the vicinity of the repository.

In more complex modelling, sometimes referred to as reactive transport modelling where solute interactions with individual mineral phases are taken into account; again the fractions of the fracture surface that is covered by individual fracture minerals are needed. Such data are provided in this article.
Another topic of importance for disposal of radioactive waste, as well as for other reservoir characterisation and contaminant transport problems, is the evolution of the groundwater composition. The evolution of redox potential is such an issue. Long-lived waste of high radioactivity, such as spent nuclear fuel, is often (planned to be) encapsulated in metallic containers such as copper canisters (e.g. POSIVA 2012; SKB 2011). The corrosion resistance of such metallic containers is highly dependent on the groundwater chemistry. For the case of copper canisters, the dissolved oxygen concentration, as well as the sulphide concentration, of the contacting groundwater is of great concern. If taking the example of dissolved oxygen, its concentration is relatively high in very nearsurface groundwater but sharply decreases when going deeper into the bedrock (Auqué et al. 2008). This is partly due to abiotic oxygen consumption as result of reactions with fracture minerals and minerals of the rock matrix (Spiessl et al. 2009; Sidborn et al. 2010). If incorporating consumption reactions with fracture minerals along the flow path in quantitative modelling, it is not sufficient to qualitatively know which fracture minerals exist at the site. When assigning an oxygen consumption capacity the individual amounts of fracture minerals are needed in terms of amount of substance, mass, or volume. In case flow path averaged data suffice, desirable input data include fracture minerals thicknesses, averaged over the fracture surface. Such data should be based on a large number of site specific observations that preferentially have been treated statistically. The same reasoning applies if estimating the capacity of fracture minerals to buffer other changes in groundwater composition, for example acidification (e.g. Luukkonen et al. 2004). Such data are provided in this article.

\section{Objective and scope}

This article presents the recently developed methodology of, and results from, an extensive campaign of quantitative fracture mineral mapping. This campaign has been carried out at the Forsmark site investigation area in Sweden, in rock volumes down to the depth of $1000 \mathrm{~m}$, by The Swedish Nuclear Fuel and Waste Management Company, SKB. More than 2000 fractures have been carefully and quantitatively mapped with regards to a handful of fracture minerals (Eklund and Mattsson 2009; Löfgren and Sidborn 2010a). To limit the scope of this article, the fracture minerals chlorite, calcite, and pyrite are focused upon. Also, this article focuses on the mapping of discrete fractures, as opposed to the mapping of occasional crush zones performed within the campaigns.

The main results provided are 1) the surface averaged fracture mineral thickness; and 2) the fraction of the fracture surface facing groundwater that is covered by a specific fracture mineral. Data from the mapping are handled statistically by both parametric and non-parametric methods. In order to see if the data differ for rock volumes at different depths and of 
different deformation history, the investigated rock volume has been divided into seven sub-volumes. Comparisons of data from these sub-volumes are made with data from the entire Forsmark rock volume. In addition, comparisons are made to data from a similar quantitative fracture mineral mapping campaign carried out at the Laxemar site in Sweden; located some $400 \mathrm{~km}$ south of Forsmark. This indicates whether the described fracture mineral situation is very specific for the Forsmark site, or is comparable with that of another site of (fairly) similar geological attributes.

This article focuses on fracture minerals from the perspective of future groundwater evolution and radionuclide retardation. The timeframe for assessing the radiological risk from a geological repository for radioactive waste is not more than one million years, which is relatively short on a geological time scale. It is not within the scope of this article to discuss the results in reference to understanding of the sites' palaeohydrogeology.

Some, but not all, of the results are found in the SKB reports (Eklund and Mattsson 2008, 2009; Löfgren and Sidborn 2010a, 2010b), were also data on other fracture minerals are reported together with an expanded set of investigated parameters and sub-volumes; especially for the Laxemar site. Also, a more detailed description of the applied mapping methodology is found in these reports. It should be noted that all SKB reports referred to have been subjected to factual review and are downloadable for free at www.skb.se. Recently, additional work has been performed on the maximum fracture coating thickness, from the perspective of diffusion resistance.

\section{The sites and previous investigations}

The Forsmark site The characterisations and site descriptions of the Forsmark and Oskarshamn sites in Sweden have been devoted an entire special issue of Applied Geochemistry (vol. 23, issue 7). For an overview, Ström et al. (2008) and Andersson et al. (2013) are recommended. Below, a short summary of the Forsmark site and site investigation is given, starting with geological and mineralogical aspects and moving on to hydrogeological and hydrogeochemical aspects.

The Forsmark site is located on the shore of the Baltic Sea about $170 \mathrm{~km}$ north of Stockholm. The area is flat and lowlying and about $10 \mathrm{~km}^{2}$ in size. Geological and geophysical downhole surveys, together with detailed mapping of the drill cores, have been conducted for 25 core drilled boreholes, with the total length of nearly $18 \mathrm{~km}$ (Andersson et al. 2013). The boreholes have been drilled from 12 drill sites, which are displayed in Fig. 1 together with the location and orientation of the boreholes. The ground surface of the drill sites of concern for this article is located between 2.5 and $8.8 \mathrm{~m}$ above sea level (SKB 2008a).
For the great majority of the borehole length, the drill core has been retrieved. The standard mapping of drill cores has been carried out while simultaneously studying images from a borehole camera, with a resolution down to $1 \mathrm{~mm}$. In addition, data from numerous of geophysical downhole tools have been used as input to the drill core mapping. Structures and lithologies are documented in detail. Based on the geological investigations, a 3D site descriptive model has been constructed featuring the distribution of rock domains, deformations zones, etc. (e.g. Follin et al. 2008; Stephens et al. 2007). The dominating rock type of the central Forsmark area, where most boreholes exist, is described as fine- to mediumgrained metamorphic granodiorite and tonalite. Subordinate rock types are pegmatite and pegmatitic granite; metamorphic fine- to medium-grained granitoid; amphibolite; fine to medium-grained granite; and metamorphic aplitic granite (Stephens 2010). Most of the bedrock was formed between 1900 and 1850 million years ago and has been subjected to both ductile and brittle deformation (Hermansson et al. 2007).

Concerning fracture mineral layers, their presence in open, partly open, and sealed fractures have been characterised, as well as in the occasional crush zone. In the standard drill core mapping, the sequence of fracture mineral layers is documented, but in practice their amounts are mapped in a qualitative fashion. This is as the lower detection limit of their thickness is $0.5 \mathrm{~mm}$, which is much too high, and as their fracture surface coverage is not estimated (Petersson et al. 2006). In additional investigations, detailed mineralogical studies have been carried out, e.g. (Tullborg et al. 2008; Sandström et al. 2008b). The relative frequency of different fracture minerals can be summarised as follows: calcite and chlorite/corrensite $>>$ laumontite $>$ quartz, adularia, albite, clay minerals $>$ prehnite, epidote $>$ hematite and pyrite, but there are large variations between fractures. Other fracture minerals have only been found as minor occurrences. No other carbonates than calcite have been found and pyrite makes up for $99 \%$ of the identified sulphides.

Based on the sequence of fracture mineralisation, four main generations (parageneses) of fracture minerals have been generally identified at the Forsmark site (Sandström and Tullborg 2009; Tullborg et al. 2008). The first generation was formed during the Precambrian between 1.8-1.1 Ga ago, at temperatures above $150-200{ }^{\circ} \mathrm{C}$ where the dominating minerals are epidote, chlorite, and quartz. Fractures coated by this generation were generally formed in the brittle regime (as for fractures coated by generation 2-4) but brittle-ductile deformation has been identified in the oldest fractures/cataclasites. The second generation was formed at temperatures between $\sim 150-280{ }^{\circ} \mathrm{C}$ relating to hydrothermal events between 1.1 and $1.0 \mathrm{Ga}$ ago. Dominating minerals are adularia, prehnite, laumontite, chlorite, and calcite. Generation 2 minerals occur as first precipitation in most fractures, indicating the formation of new fractures subsequent to the formation of generation 1 
Fig. 1 Left: Map of Sweden showing the location of Forsmark and Laxemar. Right: Map of the Forsmark site investigation area, with indicated drill sites (DS1 DS12) and core drilled boreholes (pink dot showing the surface coordinate and yellow tube indicating the orientation). Drillsite map modified from (SKB 2008a)
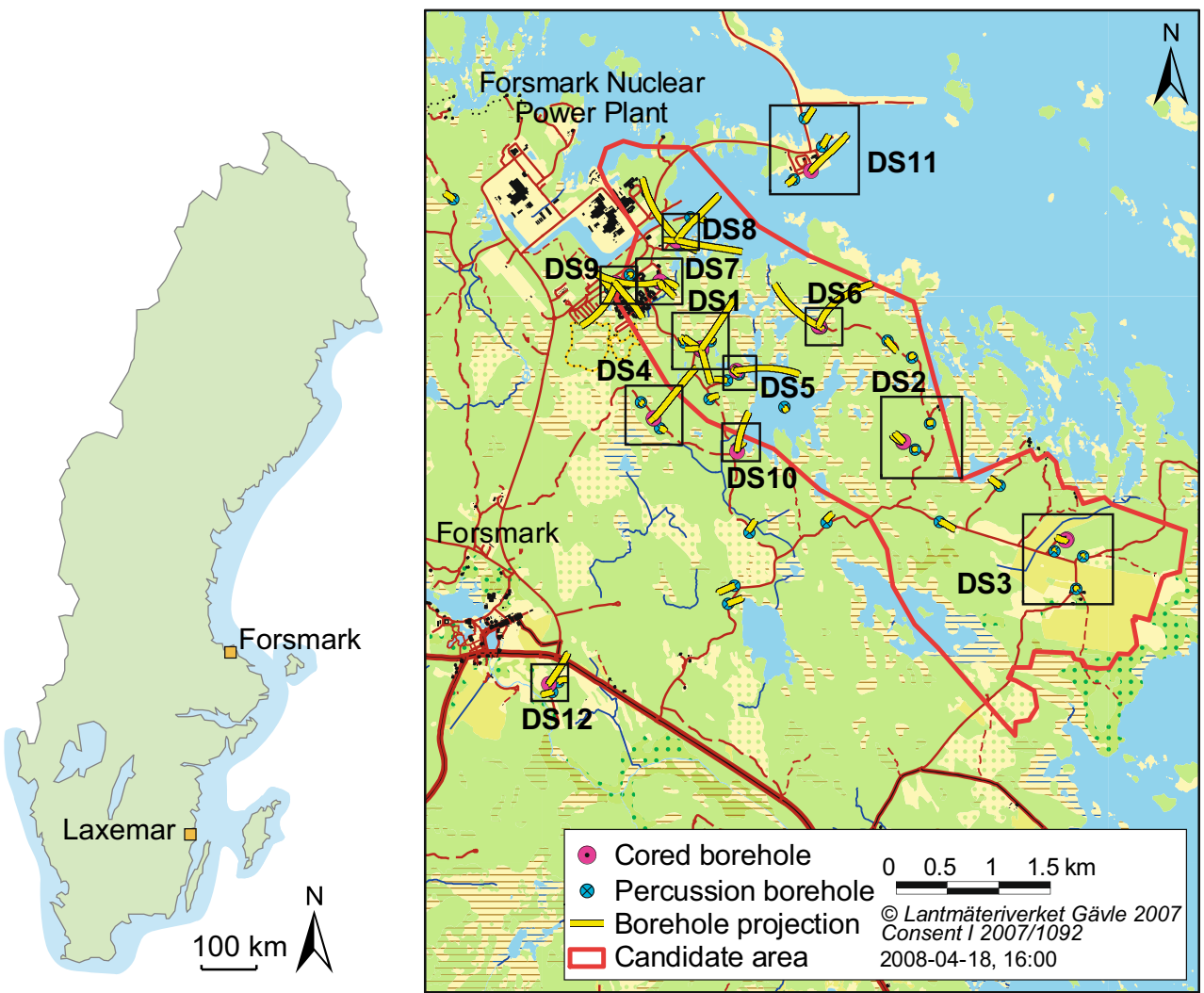

minerals. The wall rock of generation 1 and 2 fractures is commonly associated with hydrothermal alteration (Sandström et al. 2010). Generation 3 minerals were precipitated under low-temperature conditions $\left(\sim 60-190^{\circ} \mathrm{C}\right)$ and are dominated by quartz, calcite and pyrite, but also by corrensite, adularia, analcime, and asphaltite. Different generation 3 minerals have precipitated in sequence between $\sim 460-277 \mathrm{Ma}$ ago. Pyrite occurs almost exclusively as a generation $3 \mathrm{~min}-$ eral and the significant number of fractures where the pyrite is not precipitated on generation 1 and 2 minerals indicates the formation of new fractures during the Palaeozoic. In addition, generation 3 minerals are formed in reactivated fractures. Generation 4 minerals have been formed at temperatures below $50^{\circ} \mathrm{C}$, possible from late Palaeozoic to present time, and are dominated by clay minerals, chlorite/corrensite and thin coatings of calcite, together with small amounts of pyrite and goethite. They are often found in hydraulically conductive structures, of which many are reactivated fractures containing minerals of older generations (Sandström et al. 2008a; Tullborg et al. 2008; Sandström and Tullborg 2009).

This rather complex sequence of fracture mineral formation creates layers of fracture coatings that are mixtures of different fracture minerals to a lesser or larger extent. For example, chlorite is often associated with ingrowths of clay minerals, mostly corrensite. Figure 2 shows two photos of open fractures from Forsmark, clearly visualising the layered structure but also the patchwise heterogeneity of the fracture coatings.
Figure 2 also shows a backscattered electron image of a fracture coating where laumontite and analcime have crystallised in the first layer. A mixture of adularia and quartz has grown on these minerals. This demonstrates that heterogeneity also exist on the much smaller scale.

The average fracture frequency for open and partly open fractures is $0.9 \mathrm{~m}^{-1}$. As it can be difficult to estimate whether a fracture is actually open in-situ, only part of them are judged to be open with certainty. The frequency of those is on average $0.2 \mathrm{~m}^{-1}$ (Follin et al. 2007) but there is a clear decrease of this frequency with depth (Byegård et al. 2008).

From a hydrogeological point of view, groundwater is conducted in discrete open fractures, as well as in clusters of such fractures and crush zones. Evidence from the site investigation suggests that the bedrock at Forsmark, at a few hundred metres depth, conducts water along very few flow paths (Follin et al. 2008), at least at rates above the detection limit of the used logging tool. The frequency of detected flowing fractures in the investigated rock volume, below the depth of $400 \mathrm{~m}$, is $0.005 \mathrm{~m}^{-1}$, which implies a block size between flowing fractures of approximately $200 \mathrm{~m}$ (Selroos and Follin 2010). The corresponding frequency in shallow rock is much higher with $\sim 0.3 \mathrm{~m}^{-1}$ down to a depth of $200 \mathrm{~m}$, and $\sim 0.04 \mathrm{~m}^{-1}$ between 200 and $400 \mathrm{~m}$ depth (Vidstrand et al. 2010). The above data are based on hydraulic single-hole loggings conducted in the 25 core drilled boreholes of Fig. 1, down to a maximum depth of $1000 \mathrm{~m}$. For the 15 boreholes this article focuses on, the 
Fig. 2 Upper left: Open fractures of borehole KFM09B in Forsmark, at borehole lengths $226 \mathrm{~m}$, with coating of laumontite, calcite, pyrite, and quartz. Lower: Open fractures of borehole KFM01C, at $90 \mathrm{~m}$, with coating of calcite and quartz. Upper right: Backscattered electron image of a fracture coating with laumontite, analcime, adularia and quartz. Reproduced from (Sandström and Tullborg, 2005; Sandström et al.

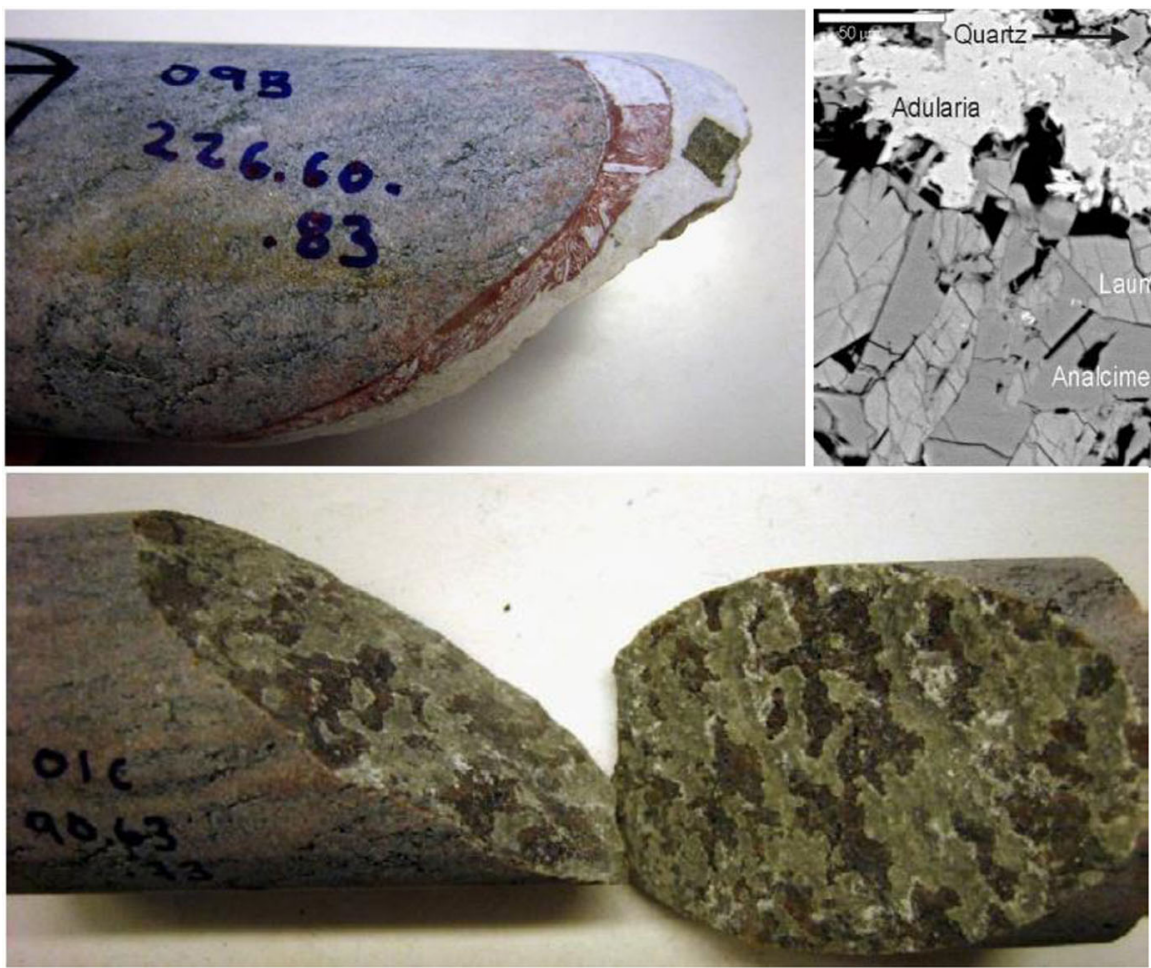
2008a)

average spacing between flowing fractures is $\sim 15 \mathrm{~m}$, but it should be noted that they are often clustered. The above data are based on quantitative loggings with the Posiva difference flow meter. Some specifics of this tool are of interest for this present article, as the data it produces constitute one of the main bases for the drill core sampling strategy. The downhole tool, also called the Posiva flow log (PFL) is specifically developed to investigate hydraulic properties of discrete fractures in sparsely fractured crystalline rock. Its measurement limit is down to $30 \mathrm{ml} / \mathrm{h}$, which translates to a transmissivity of about $10^{-9} \mathrm{~m}^{2} / \mathrm{s}$ (Väisäsvaara et al. 2006). In detailed mode, the tool packs off half a metre of the borehole and is moved in $0.1 \mathrm{~m}$ increments along the entire borehole. Hence, flow anomalies can be located with a resolution of one decimetre. The specifications of the tool, as well as typical logging and interpretation procedures are detailed in e.g. (Ludvigson et al. 2002; Sokolnicki and Heikkinen 2008).

For hydrogeochemical aspects, and their modelling, (Auqué et al. 2008; Laaksoharju et al. 2008a, 2008b; Follin et al. 2008) are referred to. In summary, the groundwater of the upper $\sim 100 \mathrm{~m}$ is mainly meteoric. Below that depth the groundwater becomes brackish and below the intended repository depth $(\sim 500 \mathrm{~m})$, increasingly saline. Except for at very shallow depths, the groundwater is reducing and measured Eh values range from -143 to $-196 \mathrm{mV}$. The $\mathrm{pH}$ buffering capacity of Forsmark groundwaters at depths greater than $100 \mathrm{~m}$ appears to be controlled by the calcite system, and modelling indicates that this water is in equilibrium with calcite. Although hydrogeochemical considerations have been made in selecting fracture minerals included in the quantitative fracture mineral mapping campaign, no elaborate consideration has been made in the drill core selection.

The Laxemar site In this article, data from the Laxemar site are only used for comparative purposes. Accordingly, only a very short summary of this site is provided. For an overview of the site and the investigations carried out, (Ström et al. 2008) is recommended. Laxemar is located within the Oskarshamn site investigation area close to the coast of the Baltic Sea in the south-eastern part of Sweden (see Fig. 1). The topography is fairly flat and low-lying but with relatively distinct valleys. The dominating rock types are characterised as equigranular, medium-grained quartz monzodiorite; medium-grained and finely porphyritic Ävrö quartz monzodiorite; and Ävrö granite. The frequency of open fractures is normally between 1 to $2 \mathrm{~m}^{-1}$ below the elevation $100 \mathrm{~m}$ below sea level (mbsl). The relative frequency of different fracture minerals shows large variation but can be summarised as follows: calcite and chlorite » epidote, quartz and clay minerals $>$ pyrite $>$ hematite, adularia and prehnite » zeolites (Tullborg et al. 2008; Drake et al. 2009a; Drake and Tullborg 2009). Fracture mineral generations at the site are discussed in (Drake et al. 2009b). From a hydrogeological point of view the rock mass at depth is more conductive than at Forsmark. This can be exemplified by the frequency of detected flowing fractures in the presumptive host rock volumes of the repository, at elevations below $400 \mathrm{mbsl}$. While this frequency is $0.005 \mathrm{~m}^{-1}$ for Forsmark, it varies between 
0.06-0.23 $\mathrm{m}^{-1}$ for different parts of the rock volume in Laxemar (SKB 2010).

\section{Materials and methods}

\section{The choice of mapped fracture minerals}

In the Forsmark and Laxemar campaigns, the fracture minerals calcite, chlorite, clay minerals (as a group excluding chlorite), hematite, and pyrite were quantitatively mapped. In addition, hematite pigmentation was qualitatively noted. It was also qualitatively noted if both fracture surfaces displayed fresh, seemingly unaltered rock (Eklund and Mattsson 2008; Eklund and Mattsson 2009). In this article we have limited the scope to calcite, chlorite, and pyrite. In the standard drill core mapping, preceding the described campaigns, calcite and chlorite had shown to be among the most common fracture minerals at both sites (Tullborg et al. 2008). Below, a few comments on how calcite, chlorite, and pyrite may affect the groundwater composition and radionuclide transport are given, although it is recognised that other issues could deserve equal attention.

Previous experience from the sites suggests that calcite is abundant in open fractures, as well as in hydraulically conductive fractures, and also covers a fairly large fraction of the fracture surface (e.g. Sandström et al. 2008b). Calcite is clearly of importance for the $\mathrm{pH}$ of the groundwater, as well as for future buffering against $\mathrm{pH}$ changes (Laaksoharju et al. 2008b). The relatively high surface coverage of calcite makes it interesting for radionuclide retardation concerning both surface related sorption and potential hindrance of solute access to the rock matrix by way of matrix diffusion. The sorption properties of calcite are also of interest. For one thing, its surface charge can be both positive and negative, depending on the groundwater composition (even within reasonable ranges), allowing for both cation and anion exchange (Zachara et al. 1993). Also, metals in their carbonate form may become immobilised by way of solid-solution formation through a dissolution-recrystallisation mechanism (Shirvani et al. 2006). Calcite also plays an important role for the carbonate system in terms of precipitation and co-precipitation, which is of interest for carbonate containing the $\mathrm{C}-14$ isotope. C-14 has been reported to be a prominent radionuclide for the combined radiological risk in recent safety assessments (POSIVA 2012; SKB 2015).

Chlorite is abundant in open and hydraulically conductive fractures, and covers a significant fraction of the fracture surface (Tullborg et al. 2008). During weathering of igneous rock, biotite is typically altered to chlorite and further on to other clay minerals. Therefore, the groundwater composition is likely more affected by chlorite related reactions in the rock matrix than by chlorite as a fracture mineral, at least in the longer time perspective. In terms of sorption, chlorite has a smaller cation exchange capacity than biotite and a number of other clay minerals (e.g. Crawford 2010). This could be translated to a relatively low $K_{a}$ value. As for calcite, there exists little information on the effective diffusivity of chlorite. As chlorite often covers the entire fracture surface, it could have a great impact on solute exchange between flow paths and the underlying rock matrix, should its porosity and effective diffusivity be sufficiently low (e.g. Widestrand et al. 2007). On the other hand, should its porosity be sufficiently large, it could enhance the retardation of non-sorbing solutes in short-term tracer tests.

Pyrite is primarily an indicator of redox conditions (Drake et al. 2009a) but it also takes part in the groundwater sulphur balance. In case the radioactive waste is contained in copper canisters, the speciation of sulphur is of interest as sulphide is an important corrodant. Except for being related to the redox conditions, pyrite does not have a significant impact on retardation. Previous experience from the site suggests that pyrite is a less abundant fracture mineral and that it most often exists as spot minerals, i.e. as small euhedral, cubic crystals typically grown on open fracture surfaces. Less frequently, pyrite has been found as layers. Therefore, pyrite should not affect matrix diffusion in general. Although pyrite surfaces are negatively charged in natural groundwaters, and do feature sorption (Widler and Seward 2002), the combined surface area is too small to be of significance for radionuclide retardation.

\section{The drill core sampling strategy}

This section gives the rationale for choosing certain boreholes at the Forsmark site, and certain drill core sections of these boreholes, for the quantitative fracture mineral mapping campaign. From a solute transport perspective, the focus should be on open fractures that conduct water, and on the properties of their fracture minerals and the adjacent rock matrix. Hence the sampling strategy was based on hydrogeological grounds. Fracture minerals confined to non-conductive rock volumes, located a metre or more distant from any flow path, will have little impact on groundwater composition and radionuclide retardation, even though they indirectly can be accessed by way of matrix diffusion (e.g. Neretnieks 1980). Based on this notion, it was decided to use the locations of flow anomalies along the boreholes as a proxy of the location of naturally occurring flow paths.

It could be rightfully argued that one cannot know how representative detected groundwater flows are for the future flow situation, when the boreholes are plugged and hydraulic gradients have changed due to shoreline displacement, climatic events, etc. Moreover, in the case of clustered fractures one cannot know which fracture will be the primary flow path when the borehole is plugged, even if the local rock volume conducts water. These uncertainties are handled in two ways. 
Firstly, not only the fracture at the direct location of the flow anomaly has been mapped, but all open fractures within the distance of $1 \mathrm{~m}$ from the flow anomaly. Such a $2 \mathrm{~m}$ drill core section is henceforth called a PFL section, where PFL relates to the hydraulic logging tool used. In case the spacing between two flow anomalies is smaller than $2 \mathrm{~m}$, the concerned PFL sections are equally shortened so that they do not overlap. Accordingly, no single fracture is accounted for twice. In total, 401 PFL sections have been mapped in Forsmark, corresponding to a combined drill core length of $767 \mathrm{~m}$. Secondly, a control volume of rock that is not presently intersected by hydraulically conductive fracture has been investigated. In total $60 \mathrm{~m}$ of drill core taken from positions at least $5 \mathrm{~m}$ distant from any detected PFL anomaly has been mapped. This facilitates comparisons with fracture mineral data from rock volumes locally intersected by flowing structures. In addition, a third category of drill core sections has been studied. Generally, the upper $100 \mathrm{~m}$ or so of the core drilled boreholes are cased, which make flow logging unfeasible. To obtain information on shallow rock, $104 \mathrm{~m}$ of drill core from the elevation range of 6 to 80 mbsl was mapped, even though the locations of flow anomalies were unknown.

For the 401 PFL sections, the following drill core sampling strategy was deployed: Within the Forsmark site investigation, a total of 769 PFL anomalies had been detected in the 25 core drilled boreholes. All of these anomalies could not be investigated, due to constraints on the campaign. A stratified random sampling strategy, followed by a systematic sampling strategy (e.g. Zhang 2007), was used when reducing the sample population from 769 to 401 anomalies. No elaborate geological or hydrogeological information was used in sample reduction. Instead the aim was to obtain a good spatial distribution of the samples, so that they represent the entire Forsmark site. As previously discussed, the deeply lying rock is much less fractured than the shallow rock. Therefore, it was decided to include all of the detected flow anomalies from below the elevation of $400 \mathrm{mbsl}$. It was also decided that drill cores from all possible drill sites (DS) should be included in the mapping campaign. For DS5, with relatively few detected anomalies, and DS10 having a borehole with an only $60 \mathrm{~m}$ long casing, all anomalies were included. To not reduce the possibility of studying the local variability between relatively adjacent flow paths for the other drill sites, it was decided that each borehole should be divided into sections, at least $20 \mathrm{~m}$ long, and that whole sections should be included or discarded. The choice was made by systematic sampling. The numbers of PFL sections, within different elevation and transmissivity ranges, are given for the different boreholes in Table 1.

For the other two categories of drill cores, the following sampling strategy was deployed: For the $60 \mathrm{~m}$ of drill core distant from any detected flow anomaly, twelve sections each $5 \mathrm{~m}$ long were selected from drill sites DS1, DS3, DS6, and DS8. This was done in a systematic manner so that the elevation range of 50 to $600 \mathrm{mbsl}$ was evenly represented. For the $104 \mathrm{~m}$ of shallow drill core taken from above the elevation $80 \mathrm{mbsl}$, where no flow logging had been performed, ten sections at least $5 \mathrm{~m}$ long were selected from drill sites DS1, DS3, DS6, and DS8. A detailed account of the sampling strategy is provided in (Löfgren and Sidborn 2010a).

\section{Methodology of quantitative fracture mineral mapping}

Upon selecting the drill core sections included in the campaign, the previously performed standard drill core mapping was consulted and all discrete fractures mapped as open were revisited. Discrete fractures previously mapped as sealed or partly open were not revisited, as flow in these fractures must be minute. In addition, crush zones were revisited. However, the spacing between crush zones is much larger than the spacing between flow anomalies. For this reason, and in the interest of limiting the scope of this article, we will not further discuss the mapping of, or results from, crush zones. For each fracture mineral layer, three parameters were mapped:

- Visible coverage of layer

- Total coverage of layer

- Thickness of layer (called mineral thickness in (Löfgren and Sidborn 2010a)).

The methodology of doing this is described with the aid of Fig. 3 showing photographs of two drill core samples at different angles, as well as an illustration of a drill core sample that features four idealised fracture mineral layers. Also consult Fig. 2. For each fracture surface the mapping geologist started by determining the individual fracture mineral layers and the sequence by which they were formed. This was done for up to four layers for each fracture surface. Thereafter, the visible coverage of each layer was determined by ocular inspection of the fracture surface from above. This can be exemplified by the top layer of calcite in the upper left photograph of Fig. 3, where the layer's visible coverage is $63 \%$. For each mineral layer, comparisons were made with graphical representations of idealised fracture surfaces at different degrees of coverage (Terry and Chilingar 1955). The graphical representations illustrate coverages of $1,2,3,5,7,10,15,20$, $25,30,40$, and $50 \%$ by different patterns of black patches (fracture minerals) on white background. For layers having visible coverages between 50 and $100 \%$, the same graphical representations were used, but now the white background represented fracture minerals.

The next step is to estimate the total coverage of each layer, even if they are covered by one or more other layers. This can be exemplified by the illustration in Fig. 3. Let us, for the sake of simplicity, assume that the rock sample is a slab and not a cylinder, but keep in mind that the cylindrical shape of the drill core complicates the estimates made by the mapping 
Table 1 Numbers of included PFL sections within different elevation (E) and transmissivity (T) ranges. Elevation is given in meters below sea level (RHB 70). The elevation at ground surface of the drill sites ranges between 2.5 and $8.8 \mathrm{~m}$ above sea level

\begin{tabular}{|c|c|c|c|c|c|c|c|}
\hline Borehole & $\mathrm{E}>100 \mathrm{mbsl}$ & $100 \geq \mathrm{E} \geq 400 \mathrm{mbsl}$ & $400>\mathrm{E} \geq 600 \mathrm{mbsl}$ & $\mathrm{E}<600 \mathrm{mbsl}$ & $T<10^{-8} \mathrm{~m}^{2} / \mathrm{s}$ & $10^{-8} \leq T \leq 10^{-6} \mathrm{~m}^{2} / \mathrm{s}$ & $T>10^{-6} \mathrm{~m}^{2} / \mathrm{s}$ \\
\hline KFM01D & 7 & 26 & 1 & - & 13 & 19 & 2 \\
\hline KFM02A & - & - & 49 & 1 & 23 & 26 & 1 \\
\hline KFM02B & 5 & 14 & 22 & - & 2 & 25 & 14 \\
\hline KFM03A & - & 12 & 10 & 11 & 11 & 19 & 3 \\
\hline KFM04A & 10 & 11 & 1 & 1 & 7 & 10 & 6 \\
\hline KFM05A & 12 & 13 & - & 2 & 10 & 13 & 4 \\
\hline KFM06A & - & 21 & 1 & 5 & 16 & 10 & 1 \\
\hline KFM07A ${ }^{a}$ & - & - & - & 3 & - & - & - \\
\hline KFM07C & 1 & 14 & - & - & 6 & 7 & 2 \\
\hline KFM08A & - & - & 3 & - & 1 & 1 & 1 \\
\hline KFM08C & - & - & 9 & - & 7 & 2 & - \\
\hline $\mathrm{KFM} 08 \mathrm{D}^{\mathrm{b}}$ & 11 & 17 & 5 & 2 & 15 & 17 & 2 \\
\hline KFM10A & 32 & 24 & - & - & 14 & 27 & 15 \\
\hline KFM11A & 21 & 21 & 3 & - & 16 & 24 & 5 \\
\hline Total & 99 & 173 & 104 & 25 & 141 & 200 & 56 \\
\hline
\end{tabular}

${ }^{\text {a }}$ No quantitative transmissivity obtained in flow logging for the three selected anomalies

${ }^{\mathrm{b}}$ No quantitative transmissivity obtained in flow logging for one selected anomaly

geologist. Moreover, fractures are often not perpendicular to the borehole axis. Let us further assume that the layers do not vary along the z-axis. In this case, the total coverage of mineral layer $\mathrm{A}$ is $50 \%$; $\mathrm{B}$ is $100 \%$; $\mathrm{C}$ is $80 \%$; and $\mathrm{D}$ is $100 \%$. It should be noted that for the top layer, the visible coverage is the same as the total coverage.

The next step is to determine the thickness of each mineral layer. This is the average thickness of the layer, but only based on the fraction where it covers the surface. If once more using the illustration of Fig. 3, the mineral thickness of layer A is $0.5 \mathrm{~mm}$. The mineral thickness of layers $\mathrm{B}$ and $\mathrm{C}$ is $1 \mathrm{~mm}$ while that of layer $\mathrm{D}$ is $1.2 \mathrm{~mm}$. In the real case, the mapping geologist should measure the layer thickness at five locations (if possible) and take the average value from these measurements. This is done with a resolution of $0.1 \mathrm{~mm}$. Note that the thickness of the individual layers to a great majority is less than $0.5 \mathrm{~mm}$. For example, in the campaign more than 2000 individual calcite layers were observed but only 1 and $3 \%$ out of these were assigned a thickness of layer $\geq 0.5$ and $\geq 1 \mathrm{~mm}$, respectively. In some articles and reports, photos of fracture coatings from the Forsmark site show rather spectacular coating thicknesses (e.g. Sandström and Tullborg 2009). Mapping data from this present study suggest that thick coatings in discrete fractures should be seen as rather rare. For pyrite in the form of spot minerals (individual crystals) facing the fracture, a different approach has been taken. The base of the
Fig. 3 Upper images: Rock samples covered by calcite beside a metric system ruler (reproduced from Eklund and Mattsson 2008). Lower image: Illustration of a rock sample covered by four idealised fracture mineral layers

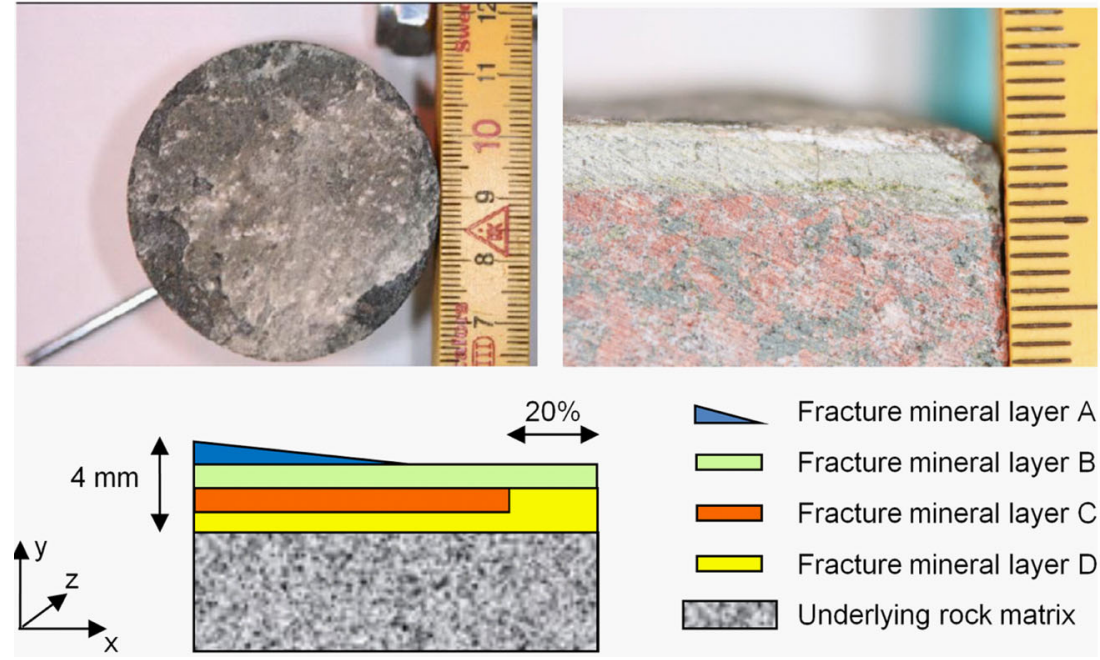


crystals is assumed to be square, and an average length of the square is given that should be representative for all crystals at the fracture surface. In addition, a representative thickness of the crystals is given. This is done with a resolution of $0.1 \mathrm{~mm}$. Finally the number of spots per $\mathrm{cm}^{2}$ is given.

\section{Calibration and uncertainty of mapping data}

Calibrations were made by comparing the mapping data, based on ocular inspection, with similar data based on digital image analyses of photographed drill core samples. This approach has limitations in that details in the inmixing of other minerals cannot be readily determined. Using detailed analysis such as Scanning Electron Microscope, X-ray diffraction or elemental analysis (e.g. Gilkes et al. 1980; Drake et al. 2009a) would possibly have improved the calibration in this regard (cf. the backscattered electron image in Fig. 2). On the other hand, it is not straightforward to quantitatively link calibration data from detailed analyses of a few fracture mineral patches with those of this extensive mapping campaign. When mapping over 4000 fracture surfaces, a simplified handling must be enforced. For example, layers of calcite are typically identified by their reaction with a dilute acid. Even if there was substantial inmixing of other minerals, this reaction (release of $\mathrm{CO}_{2}$ ) is expected. Hence there is substantial and unquantified uncertainty regarding the purity of the mapped minerals. However, the skilfulness of the mapping geologists advocates that the mixed mineral to a majority consists of the mineral by which it was designated.

Concerning the visible coverage, a calibration has been made based on 30 fracture surfaces and 54 fracture mineral layers, based on digital image analysis. Prior to this, the visible coverage of the layers had been estimated by ocular inspection. The difference between the two methods was on average $\sim 4 \%$ of the total surface with a standard deviation of $\sim 3 \%$ (calculated from data in (Eklund and Mattsson 2008; Eklund and Mattsson 2009)). The maximum deviation was $11 \%$. The estimated generic uncertainty linked to the usage of the graphical representations of (Terry and Chilingar 1955) is for each percentage interval given within the parentheses: 1-3 (1\%); 3-7 (2\%); 7-10 (3\%); 10-30 (5\%); and 30-50 $(10 \%)$. Estimating the total coverage is judged to be more complicated and thus requires an experienced eye that inspects the rock sample from all angles. No formal uncertainty estimation was made but one can assume that the uncertainty may be up to a few times larger when estimating the total coverage of underlying layers, as compared to the visible coverage of the top layer.

Concerning the mineral thickness, a calibration was made based on 7 fracture surfaces and 8 fracture mineral layers. In this case the drill core perimeter has been photographed and subjected to digital image analysis. When comparing the ocular and digital image analysis estimates, the error was on average $\sim 0.04 \mathrm{~mm}$, with the maximum deviation of $0.12 \mathrm{~mm}$ (calculated from data in (Eklund and Mattsson 2008)). Concerning the uncertainty of pyrite amounts, it most prominently originates in the methodology of averaging of crystals' bases and thicknesses. The combined volume of one large crystal and a few smaller crystals can be significantly larger than the product of their average base and thickness, times the number of crystals. Hence the presented data may underestimate the pyrite amounts.

\section{Methodology of data refinement}

The below results are given per fracture mineral, and not per fracture mineral layer. This means that if two layers consist of the same mineral, the results from these two layers are summarised. The delivered output parameters from the data refinement are:

- $C_{\mathrm{vis}}(\%)$ : Visible coverage.

- $d_{\text {mean }}(\mathrm{mm})$ : Averaged fracture mineral thickness.

- $n_{\text {tot }}(-)$ : Total number of mapped fractures within a defined sub-volume.

- $n_{\text {qual }}(-)$ : Number of (qualitative) occurrences of a certain mineral within the sub-volume.

- $n_{\text {quant }}(-)$ : Number of occurrences where $d_{\text {mean }}$ could be quantitatively estimated for a certain mineral.

Concerning $C_{\mathrm{vis}}$, the visible coverage of each mineral of both the upper and lower fracture surfaces is summarised. The result is thereafter divided by two, so that an (average) visible coverage for the two fracture surfaces is given. This is done as one in contaminant transport problems often speaks of the flow wetted surface, where the surface areas of both the upper and lower fractures of the flow path are added.

Concerning $d_{\text {mean }}$, the following arithmetic operations are performed. Firstly the estimated mineral thickness of each layer is multiplied with the total coverage of this layer. If two or more layers contain the same minerals, the outcome of the former operation is summarised for both fracture surfaces. This can be illustrated with the aid of Fig. 3. Let us assume that Fig. 3 represents the lower fracture surface and that mineral layers A and D consist of calcite. The mineral thickness of layers $\mathrm{A}$ and $\mathrm{D}$ are 0.5 and $1.2 \mathrm{~mm}$, respectively. Their total coverages are $50 \%$ and $100 \%$, respectively. Let us further assume that the upper fracture surface features one layer of calcite, with a thickness of $0.4 \mathrm{~mm}$ and total coverage of $80 \%$. The averaged fracture mineral thickness, $d_{\text {mean }}$, is then calculated by $(0.5 \mathrm{~mm} \cdot 50 \%+1.2 \mathrm{~mm} \cdot 100 \%+$ $0.4 \mathrm{~mm} \cdot 80 \%) / 100 \%=1.77 \mathrm{~mm}$. It should be highlighted that this result is not averaged on the two fracture surfaces, as done for $C_{\text {vis. }}$.

The following should be noted concerning minerals that could be either quantitatively or only qualitatively mapped. 
When a detectable mineral layer has a thickness well under $0.1 \mathrm{~mm}$, it was qualitatively noted. On the other hand, when a mineral layer constitutes just a speck on the surface, it was assigned the quantitative coverage of $1 \%$.

When calculating the diffusion resistance of the fracture coating (here used as a collective term for all mineral layers at a fracture surface), it is useful to know its total thickness. However, due to a lapse in the mapping methodology no instruction was given to measure the fracture coating thickness. We can however examine the bounds of this thickness. The maximum fracture coating thickness, $d_{\mathrm{c}, \max }(\mathrm{mm})$ is calculated by summation of all layer thicknesses recorded for a fracture surface. In doing this, all recorded mineral layers are included and not only those of calcite, clay minerals, and pyrite. However, spot minerals are disregarded. Layers that were only recorded qualitatively are, for this particular calculation, assigned a thickness of $0.05 \mathrm{~mm}$, which is half the detection limit in the mapping campaign. Not all mineral layers cover the entire fracture surface (cf. Fig. 3). Consequently $d_{\mathrm{c}, \max }$ will overestimate the true fracture coating thickness. An alternative approach is to weigh the thickness of each layer with its total coverage in a calculation that is similar to that of $d_{\text {mean }}$. Here the fracture coating thickness $d_{\mathrm{c}}(\mathrm{mm})$ is calculated by summing the product of the layer thickness and total coverage for all layers at one surface. Again, layers that were only recorded qualitatively are given the thickness $0.05 \mathrm{~mm}$.

\section{Sorting data into sub-volumes}

At the Forsmark site, the fracture minerals of in total 2071 open fractures have been quantitatively mapped. To investigate potential differences between different rock volumes, these fractures have been divided on the following five subvolumes: Ground surface down to the elevation $100 \mathrm{mbsl} ; 100$ to $300 \mathrm{mbsl}, 300$ to $500 \mathrm{mbsl} ; 500$ to $700 \mathrm{mbsl}$; and 700 to $1000 \mathrm{mbsl}$. Furthermore, the rock hosting the fractures is sorted into the sub-volumes "within geological deformation zones" and "outside geological deformation zones". Whether a section of the drill core is located within or outside a deformation zone (DZ) has previously been determined in the site descriptive modelling (see Follin et al. 2008). Within the site descriptive modelling, rock volumes outside of deformation zones are divided into fracture domains (FD) based on their different properties, as detailed in (Stephens et al. 2007). The numbers of fractures, as well as of obtained data points, within different rock sub-volumes are shown in Table 2. In (Löfgren and Sidborn 2010a), data were also sorted into different rock domains and different orientations of deformation zones. These results are omitted to limit the scope of this article.

The sorting of data into different sub-volumes, as well as the basic arithmetic operations discussed above and the subsequent statistical treatment of the data, were performed using the numerical computing software Matlab ${ }^{\circledR}$. The exception is for the parameter $d_{\mathrm{c} \text {,max }}$, where the calculations were made in MS Excel®. Even if it, from an outline perspective, would be more logical to present the methodology of the statistical analysis here; we believe that it is more easily grasped if discussed together with the statistical results in the section below. What can be said is that for each fracture mineral, and for each data sub-volume, statistical analyses of $C_{\text {vis }}$ and $d_{\text {mean }}$ have been performed by non-parametric and parametric methods.

\section{Results}

\section{Frequency of fracture minerals}

The frequency of fractures that were found to be populated by calcite, chlorite, and pyrite are shown in Fig. 4. The data are presented for all fractures included in the mapping campaign in the Forsmark area; fractures at selected depth intervals; and all fractures located in fracture domains and deformation zones. Data for all mapped fractures in the Laxemar campaign are included for comparison. When a surface coverage was noted but the layer thickness was not sufficient to be quantified by the used methodology; the occurrence was recorded as qualitative only. All occurrences of pyrite are quantitative in accordance with the mapping methodology for individual pyrite crystals. A relative increase in chlorite frequency with depth is noted in Fig. 4, while that of calcite appears to decrease slightly with depth. It should be emphasised that deeply lying rock is much more sparsely fractured than shallowly lying rock (Follin et al. 2007). As a consequence, fewer fractures have been mapped in deeply lying sub-volumes (see Table 2). This implies that the related frequencies are subject to a larger uncertainty (see further discussion below). No significant difference in frequency can be seen between fracture domains and deformation zones. Comparing between the Forsmark and Laxemar sites, the frequency of populated fractures is higher in Laxemar for the concerned fracture minerals.

Data from sections located at a distance of more than five metres from any detected flow anomaly (so called non-PFL sections) were found to agree relatively well with the data from PFL sections. The arithmetic mean and standard deviation of the averaged fracture mineral thickness, $d_{\text {mean }}$, of the non-PFL Forsmark data for calcite (6 samples), chlorite (18 samples) and pyrite (1 sample) were found to be $0.12(0.048)$, $0.25(0.21)$, and $0.002(-)$ millimetres respectively, which compare well with the full data sets in Table 3. This justifies the inclusion of these data, as well as the data from shallow rock where no flow logging was performed, in the analysis. 
Table 2 Total number of mapped fractures, and quantitative and qualitative fracture mineral occurrences in the different sub-volumes. Data from all mapped fractures in Laxemar are included for comparison

\begin{tabular}{|c|c|c|c|c|c|c|c|c|c|c|}
\hline & & $\begin{array}{l}\text { All } \\
\text { Forsmark }\end{array}$ & $\begin{array}{l}\text { GS }-100 \\
\text { mbsl }\end{array}$ & $\begin{array}{l}100-300 \\
\text { mbsl }\end{array}$ & $\begin{array}{l}300-500 \\
\text { mbsl }\end{array}$ & $\begin{array}{l}500-700 \\
\text { mbsl }\end{array}$ & $\begin{array}{l}700-1000 \\
\mathrm{mbsl}\end{array}$ & $\begin{array}{l}\text { All } \\
\text { FD }^{\mathrm{a}}\end{array}$ & $\begin{array}{l}\text { All } \\
\text { DZ }^{\mathrm{a}}\end{array}$ & $\begin{array}{l}\text { All } \\
\text { Laxemar }\end{array}$ \\
\hline \multicolumn{11}{|c|}{ Total number of } \\
\hline Fractures & $n_{\text {tot }}$ & 2071 & 835 & 531 & 543 & 114 & 48 & 602 & 1333 & 1852 \\
\hline \multirow[t]{2}{*}{ Calcite } & $n_{\text {quant }}$ & 673 & 298 & 184 & 148 & 32 & 11 & 199 & 422 & 936 \\
\hline & $n_{\text {qual }}$ & 1177 & 486 & 320 & 287 & 62 & 22 & 357 & 725 & 1459 \\
\hline \multirow[t]{2}{*}{ Chlorite } & $n_{\text {quant }}$ & 505 & 173 & 115 & 142 & 43 & 32 & 139 & 338 & 844 \\
\hline & $n_{\text {qual }}$ & 1077 & 349 & 310 & 291 & 91 & 36 & 333 & 670 & 1322 \\
\hline Pyrite & $n_{\text {quant }}$ & 202 & 70 & 86 & 27 & 15 & 4 & 58 & 138 & 352 \\
\hline
\end{tabular}

${ }^{a}$ Note that the number of fractures defined as All FD and All DZ do not sum up to the total number in the All Forsmark data set. The reason is that 122 sampled fractures from borehole KFM11A have neither been assigned to a fracture domain nor a deformation zone in the site descriptive modelling, and that 14 samples from sections assigned as possible but non-conclusive deformation zones were discarded from the All DZ data set

\section{Non-parametric results of averaged fracture mineral thickness}

The data on the averaged fracture mineral thickness $\left(d_{\text {mean }}\right)$ were subjected to non-parametric statistical analysis. The results for different sub-volumes at Forsmark are shown in Fig. 5, where the left-hand graphs show the arithmetic mean values and standard deviations, together with $95 \%$ confidence intervals of the expected mean values. The confidence intervals are based on the assumption that the data within each sub-volume are samples of the same population (Snecdecor and Cochran 1991; NIST 2012). Although the arithmetic mean values differ significantly between the different sub-volumes at Forsmark, their confidence intervals generally overlap for chlorite and pyrite. For calcite, the shifts in confidence intervals between different sub-volumes are slightly larger. For each mineral, the differences in mapped data between sub-volumes indicate that they are not likely to be samples of the exact same population. However, the similarities suggest that the sampled populations are related. This is indicated for chlorite and pyrite in particular. A Kruskal-Wallis test (Kruskal and Wallis 1952; NIST 2012) was used to formally examine if the data from different subvolumes are part of the same statistical population. The returned significance levels of $48 \%$ and $13 \%$ for chlorite and pyrite, respectively, support the notion that $d_{\text {mean }}$ data of the different sub-volumes are part of individual populations, and that the populations are related. The test also indicates that $d_{\text {mean }}$ data for calcite of different sub-volumes differ to a greater extent (for which a significance level of $0.02 \%$ was returned). The right-hand graphs in Fig. 5 show the cumulative distribution functions for each of the Forsmark sub-volumes (thin blue lines) as well as for all sampled data (thick lines) from Forsmark and Laxemar. These figures

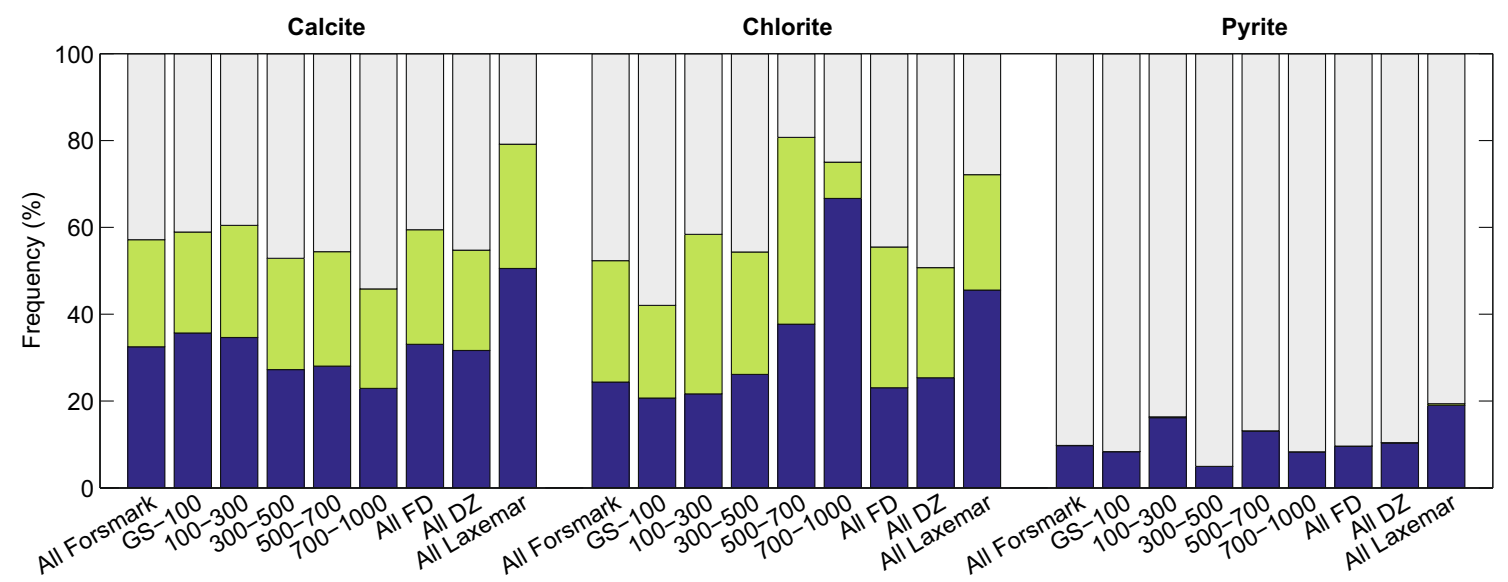

Fig. 4 Frequency of fractures populated by calcite, chlorite and pyrite, in selected rock sub-volumes in the Forsmark area. Blue bars stand for quantitative observations and green bars for qualitative observations only. Data are presented for all mapped fractures at Forsmark, for selected depth intervals ranging from the ground surface (GS) to $1000 \mathrm{mbsl}$, and for fractures located in fracture domains (FD) and in deformation zones (DZ). Mapped fractures from the entire Laxemar campaign are included for comparison 
Table 3 Percentiles, arithmetic mean, and standard deviation of sampled $d_{\text {mean }}$ and $C_{\mathrm{vis}}$ of calcite, chlorite, and pyrite from all mapped fractures in the Forsmark area. Number of significant digits does not reflect data uncertainty

\begin{tabular}{lllllll}
\hline & $\boldsymbol{d}_{\text {mean }}$ & \multicolumn{5}{c}{$\boldsymbol{C}_{\text {vis }}$} \\
\hline CDF & Calcite (mm) & Chlorite (mm) & Pyrite $(\mu \mathrm{m})$ & Calcite (\%) & Chlorite (\%) & Pyrite (\%) \\
Min & $0.001^{*}$ & $0.001^{*}$ & $0.001^{*}$ & $0.5^{*}$ & $0.5^{*}$ & $0.0005^{*}$ \\
$1 \%$ & $0.001^{*}$ & 0.005 & $0.001^{*}$ & $0.5^{*}$ & 1.0 & $0.0005^{*}$ \\
$5 \%$ & 0.002 & 0.015 & $0.001^{*}$ & $0.5^{*}$ & 2.5 & $0.0005^{*}$ \\
$10 \%$ & 0.004 & 0.033 & 0.002 & 1.0 & 5.0 & 0.0010 \\
$30 \%$ & 0.015 & 0.089 & 0.016 & 3.0 & 15.0 & 0.0045 \\
$50 \%$ & 0.040 & 0.130 & 0.081 & 6.0 & 30.0 & 0.0200 \\
$70 \%$ & 0.090 & 0.195 & 1.000 & 19.0 & 52.5 & 0.4960 \\
$90 \%$ & 0.228 & 0.329 & 4.000 & 50.0 & 84.6 & 1.5000 \\
$95 \%$ & 0.406 & 0.500 & 8.000 & 70.0 & 92.5 & 2.4000 \\
$99 \%$ & 1.330 & 2.300 & 56.04 & 95.4 & 100 & 5.9600 \\
Max & 2.000 & 7.000 & 151.0 & 100 & 100 & 8.5000 \\
Mean & 0.107 & 0.216 & 2.328 & 17.5 & 37.8 & 0.4511 \\
Std & 0.230 & 0.444 & 11.62 & 22.4 & 29.3 & 1.0568 \\
\hline
\end{tabular}

${ }^{*}$ Lower measurement limit further illustrate the similarity between the different subvolumes for each of the studied minerals at Forsmark. The sub-volumes that deviate the most contain few samples (see Table 2), reflected by the few steps in the jagged curves, and are therefore subject to a larger uncertainty. Results from the Laxemar site are included for comparison. Numerical data of the percentiles, arithmetic means, and standard deviations for the All Forsmark sub-volume are summarised in Table 3.

\section{Parametric results of averaged fracture mineral thickness}

In the non-parametric analysis, relatively small differences in $d_{\text {mean }}$ data were observed between the different sub-volumes. This justifies the simplification to treat data from the different sub-volumes as samples of the same statistical population, for each mineral, in the parametric analysis. This simplification is further justified as the data are intended for solute transport modelling, where flow path averaged values are in focus. It is
Fig. 5 Non-parametric results of the averaged fracture mineral thickness $\left(d_{\text {mean }}\right)$ of calcite, chlorite, and pyrite for mapped fractures from the entire Forsmark campaign and in the different subvolumes. The results from all mapped fractures in Laxemar are included for comparison. In the left-hand graphs the arithmetic mean (black dot) and standard deviation (green range) are shown together with a $95 \%$ confidence interval (black range) of the expected mean value of the population. The right-hand graphs show the cumulative distribution function of $d_{\text {mean }}$ in all mapped fractures in Forsmark and Laxemar (thick lines) and for the individual Forsmark sub-volumes (thin lines)
Calcite
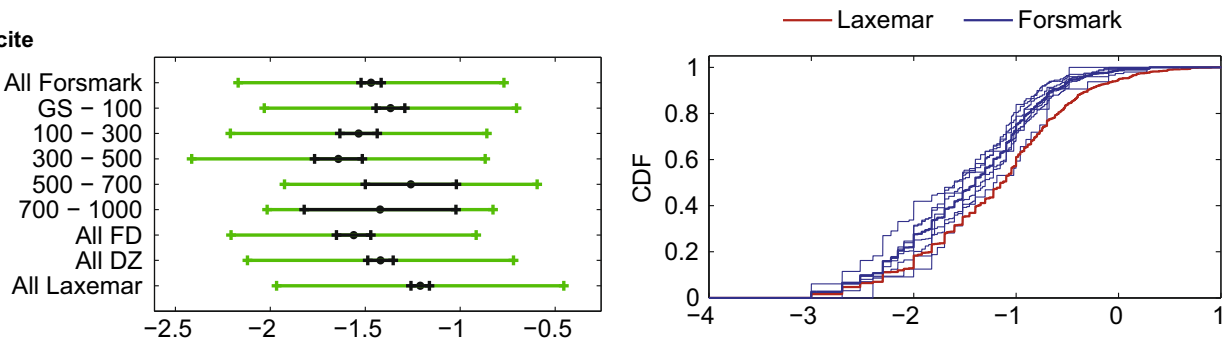

Chlorite
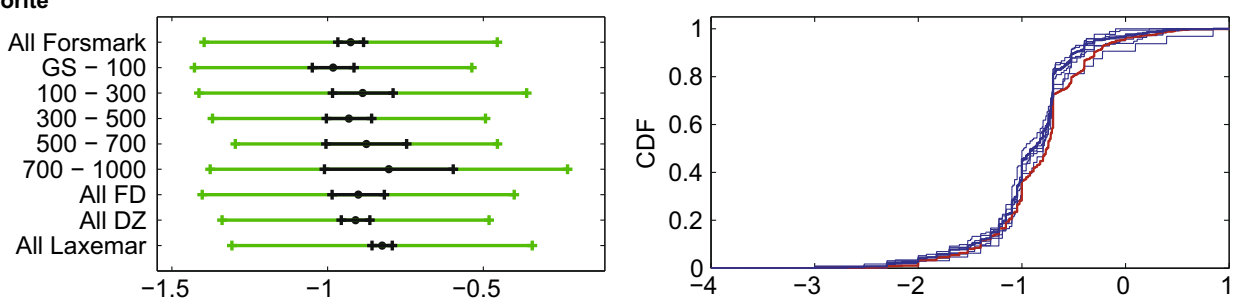

Pyrite
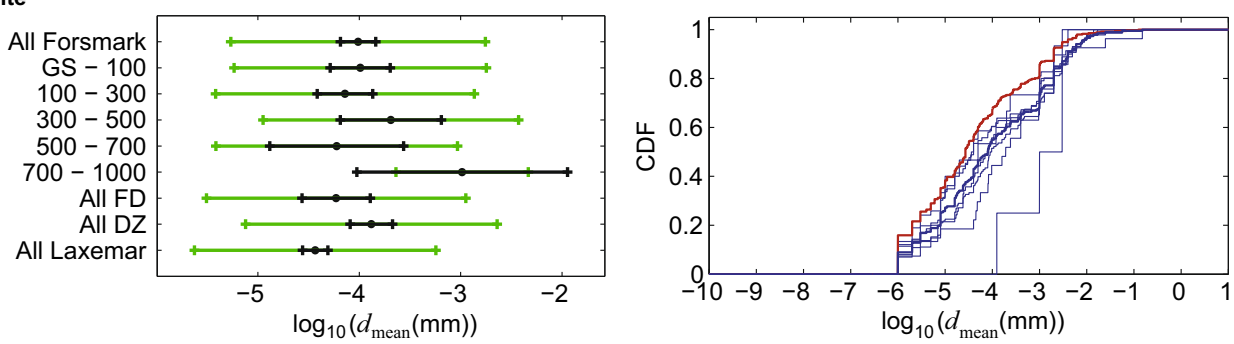
further supported by comparing an expanded set of sub-volumes, showing the same tendency of limited differences between sub-volumes (Löfgren and Sidborn 2010a).

The full data set for each mineral at Forsmark and Laxemar (represented by the thick lines in Fig. 5) were tested for normality by means of the Shapiro-Wilk W-test (Shapiro and Wilk 1965). The test is based on linear regression of ordered observations and returns a value between zero and one, where increasing values reflect a higher degree of normality. The test clearly indicates the lack of normality of the sampled $d_{\text {mean }}$ data in normal space, but the degrees of normality of the logarithmic data $\left(\log _{10} d_{\text {mean }}\right)$ of the full data sets in Forsmark were found to be $0.99,0.93$, and 0.96 for calcite, chlorite, and pyrite respectively. This suggests that the logarithm of the data is well or fairly well described by the normal distribution. The deviation of $\log _{10} d_{\text {mean }}$ from normality may partly be explained by bias emanating from the performance of the mapping methodology. In particular for chlorite, two distinct values of the mineral thickness $\left(\log _{10} d_{\text {mean }}=-1\right.$ and -0.7 ) are suspiciously over-represented, as is seen by the sudden increases in the CDFs of Fig. 5. A similar deviation from normality for the pyrite data at $\log _{10} d_{\text {mean }}=-6$ and -3 is noted. Over-representation of these particular values relates to rounding issues close to the quantification limits of the mineral layer coverage and thickness, as well as of spot mineral characteristics. An additional explanation for more general deviations from the proposed distribution is that $d_{\text {mean }}$ simply is not perfectly log-normally distributed. Although the product of two stochastic parameters should be log-normally distributed, there is no ground to claim that the underlying parameters (in this case the thickness of the mineral layers and their total coverage) are stochastic. The mineral layers are formed as result of processes in a complex chain of events that may not yield stochastic properties. It should be emphasised that the choice of coercing the data into parametric distributions is made to facilitate subsequent usage of the data in solute transport modelling.

For the Laxemar site, equally high degrees of normality for $\log _{10} d_{\text {mean }}$ data were found as for the Forsmark site, together with similar biases. In the subsequent parameterisation, the sampled data are assumed to be log-normally distributed. The distribution parameters (mean and standard deviation) were obtained from the intercept and slope of a fitted linear regression in a normal score plot (see further Johnson 1994). The resulting fitted parametric distributions are shown in Fig. 6 (smooth curves) plotted together with the cumulative distribution function of the sampled data (jagged curves). The fitted log-normal probability distributions are described by Eqs. 3 and 4 (Table 4) for the probability density function $f\left(\log _{10} d_{\text {mean }}\right)$ and cumulative distribution function $F\left(\log _{10} d_{\text {mean }}\right)$ respectively, and with the distribution parameters listed in Table 5 .

\section{Non-parametric results of visible coverage}

In Fig. 7, cumulative distribution functions of the sampled visible coverage are shown for each of the studied minerals at Forsmark. As in Fig. 5, the thin blue lines represent the individual sub-volumes and the thick lines represent all data at Forsmark and at Laxemar. As for the $d_{\text {mean }}$, the different sets of visible coverages of different sub-volumes at Forsmark are relatively similar with respect to arithmetic mean and standard deviation. Even though the results shown in the top row CDFs in Fig. 7 indicate that the $C_{\mathrm{vis}}$ data from the different sub-volumes are not likely to be samples of the exact same population, they suggest that the data sets are related, at least for chlorite and pyrite. Kruskal-Wallis tests also support that the populations of chlorite and pyrite are related across the different sub-volumes. The significance levels returned were $57 \%$ and $47 \%$ for chlorite and pyrite, respectively, whereas the significance level of calcite was less than $0.01 \%$. This latter level indicates significant differences between sub-volumes. Numerical data on the arithmetic mean, standard deviation, and percentiles of the sampled $C_{\text {vis }}$ data from the entire Forsmark campaign are summarised in Table 3.

\section{Parametric results of visible coverage}

Despite the relatively low significance levels of the KruskalWallis tests, especially for calcite, the simplification was made to treat data from different sub-volumes as samples of a single population, for each mineral, in the parametric analysis. This is partly justified with reference to the purpose of this paper, which is to provide data to solute transport modelling, and partly based on the similarities in the sub-volumes' arithmetic means and standard deviations.

In the parameterisation of the visible coverage data, the distribution was assumed to be continuous in the valid range $(0-100 \%)$. Two different distribution functions have been fitted to the sampled coverage; assuming truncated lognormally distributed data as in (Löfgren and Sidborn 2010a) and also beta distributed data. The truncated log-normal distribution of $C_{\mathrm{vis}}$ is described by Eqs. 5 and 6 (Table 4), in terms of the probability density function $f\left(\log _{10} C_{\mathrm{vis}}\right)$ and the cumulative distribution function $F\left(\log _{10} C_{\mathrm{vis}}\right)$. The fitted distribution location and scale parameters are given in Table 5, and the upper tail truncation limit is $b=\log _{10}(100 \%)=2$. The distribution mean and standard deviation were obtained from linear regression in a normal score plot as described for $d_{\text {mean }}$ above. The beta distribution shape parameters $\alpha$ and $\beta$ given in Table 5 were estimated from the sample mean and standard deviation by the method of moments (e.g. NIST 2012). The probability density function and cumulative distribution 

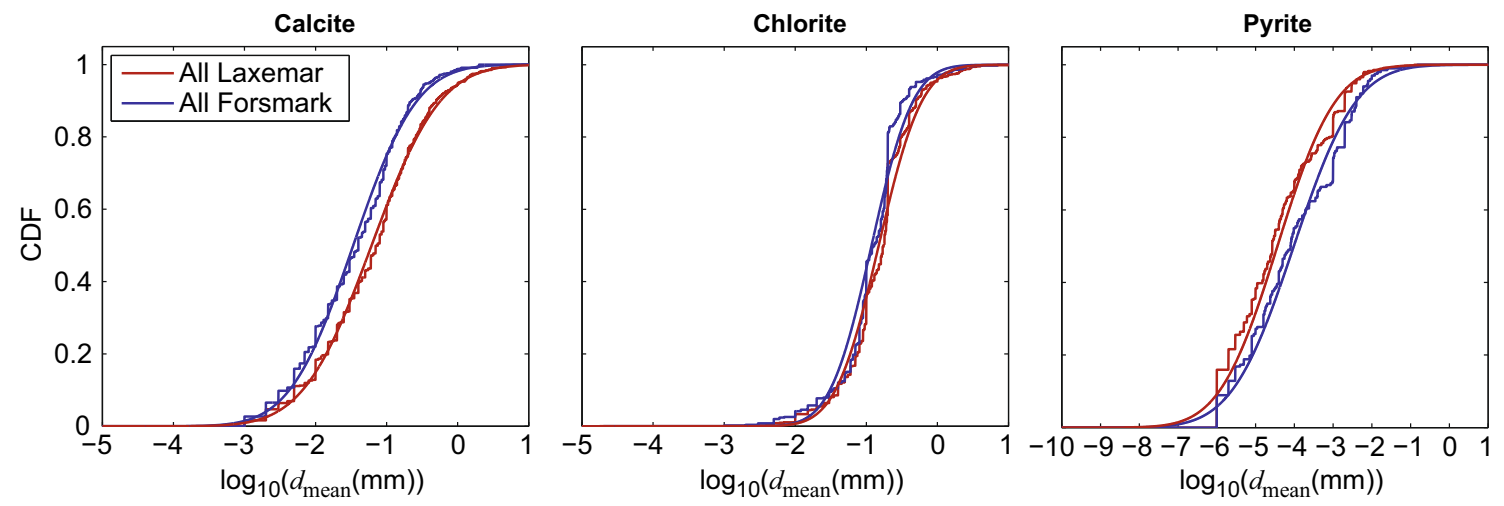

Fig. 6 Fitted cumulative log-normal distributions (smooth curves) and the corresponding cumulative distribution functions (jagged curves) of the sampled averaged fracture mineral thickness $\left(d_{\text {mean }}\right)$ of all mapped

fractures in Forsmark (blue curves) and in Laxemar (red curves). The lognormal distribution parameters are shown in Table 5

function of the fitted beta distributions are described by Eq. 7 through 9 (Table 4).

The resulting fitted beta and truncated log-normal distributions are shown together with the sampled data in the bottom row of graphs in Fig. 7. The truncated log-normal distributions show a better fit to the lower tail of the sampled data ( $C_{\text {vis }}<10 \%$ for calcite and chlorite), whereas the beta distributions more accurately represent the sampled calcite and chlorite data in the $C_{\text {vis }}$ range $10-100 \%$. The range of visible coverage of interest and the desired level of conservatism for a specific application are therefore important considerations in the choice of a suitable parameterisation. A general recommendation of which to choose can thus not be given.

\section{Fracture coating thickness}

For the fracture coating thickness, $d_{\mathrm{c}}$, and maximum fracture coating thickness, $d_{\mathrm{c}, \max }$, a limited study has been made including only the "All Forsmark" data set. Figure 8 shows the cumulative distribution functions of $d_{\mathrm{c}, \max }$ (left) and $d_{\mathrm{c}}$ (right)
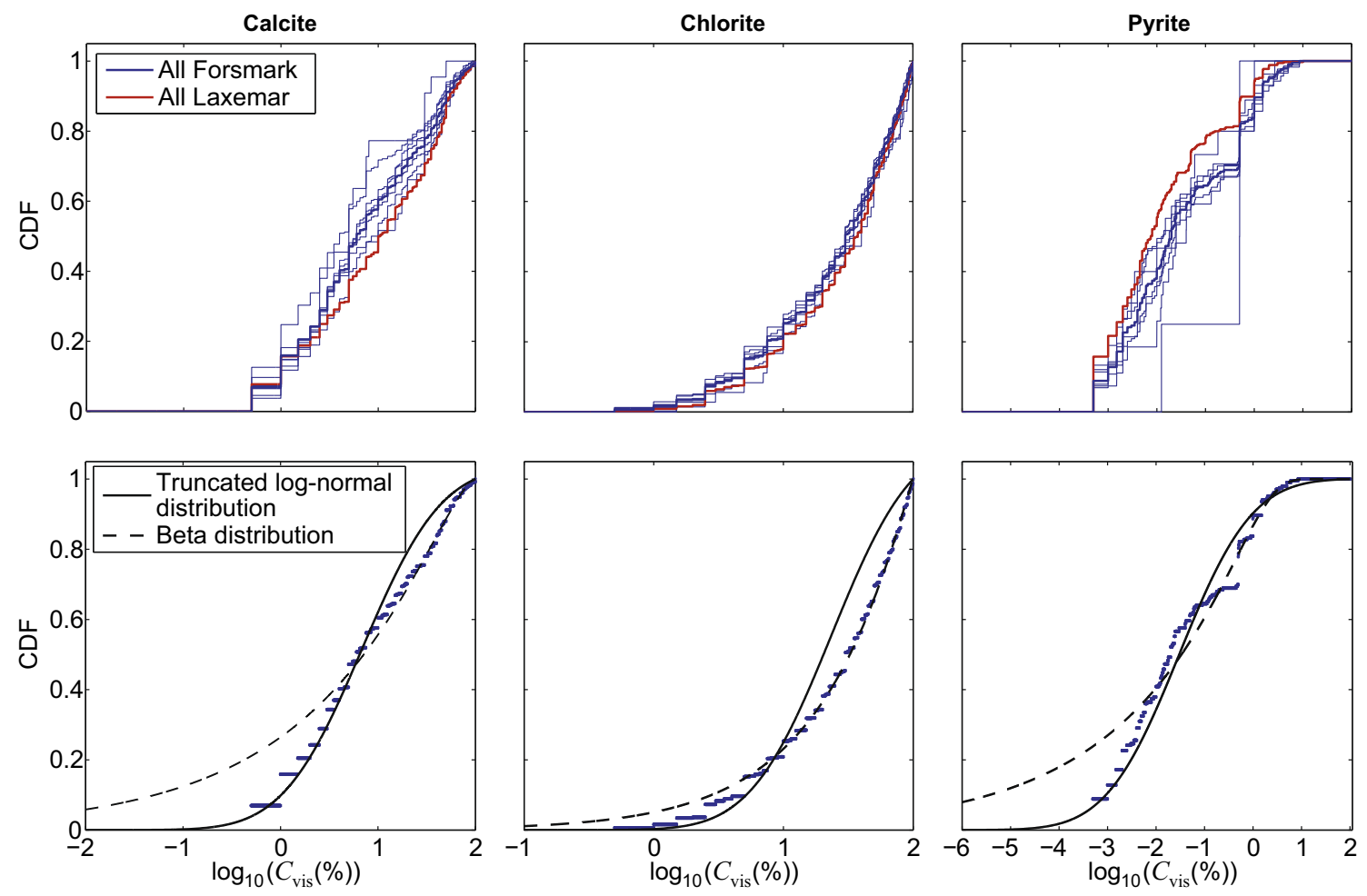

Fig. 7 Top row: Cumulative distribution functions of the sampled visible coverage $\left(C_{\text {vis }}\right)$ of calcite, chlorite, and pyrite in the selected sub-volumes in Forsmark. Results for all mapped fractures in Laxemar are included for

comparison. Bottom row: Cumulative distribution functions of all Forsmark samples (blue dots) and the corresponding fitted truncated log-normal and beta distributions. The distribution parameters are shown in Table 5 
Table 4 Probability density functions $\mathrm{f}_{i}(x)$ and cumulative distribution functions $\mathrm{F}_{i}(x)$, where index $i$ are $\mathrm{SN}$, GN, TN or B denoting the standard normal, general normal, truncated normal and beta distributions respectively

Standard normal distribution of a variable $x$ (with location and scale parameters $\mu=0$ and $\sigma=1$, respectively):

$\mathrm{f}_{\mathrm{SN}}(x)=\exp \left(-x^{2} / 2\right) / \sqrt{2 \pi} \quad 1 \quad \mathrm{~F}_{\mathrm{SN}}(x)=(1+\operatorname{erf}(x / \sqrt{2})) / 2$

General normal distribution of $x$ with location and scale parameters $\mu$ and $\sigma$, respectively:

$\mathrm{f}_{\mathrm{GN}}(x)=\frac{1}{\sigma} \mathrm{f}_{\mathrm{SN}}\left(\frac{x-\mu}{\sigma}\right)$

$$
\mathrm{F}_{\mathrm{GN}}(x)=\mathrm{F}_{\mathrm{SN}}\left(\frac{x-\mu}{\sigma}\right)
$$

Truncated normal distribution with location and scale parameters $\mu$ and $\sigma$, respectively, with upper tail truncation at $x=b$ :

$\mathrm{f}_{\mathrm{TN}}(x)=\frac{1}{\sigma} \mathrm{f}_{\mathrm{SN}}\left(\frac{x-\mu}{\sigma}\right) / \mathrm{F}_{\mathrm{SN}}\left(\frac{b-\mu}{\sigma}\right)$

$$
\mathrm{F}_{\mathrm{TN}}(x)=\mathrm{F}_{\mathrm{SN}}\left(\frac{x-\mu}{\sigma}\right) / \mathrm{F}_{\mathrm{SN}}\left(\frac{b-\mu}{\sigma}\right)
$$

Beta distribution of a variable $0 \leq x \leq 1$ with shape parameters $\alpha$ and $\beta$ :

$\mathrm{f}_{\mathrm{B}}(x)=x^{\alpha-1}(1-x)^{\beta-1} / \mathrm{B}(x=1 ; \alpha, \beta)$

$\mathrm{F}_{\mathrm{B}}(x)=\mathrm{B}(x ; \alpha, \beta) / \mathrm{B}(x=1 ; \alpha, \beta)$

where the beta function $\mathrm{B}(x=1 ; \alpha, \beta)$ and the incomplete beta function $\mathrm{B}(x ; \alpha, \beta)$ are defined by:

$\mathrm{B}(x ; \alpha, \beta)=\int_{0}^{x} t^{\alpha-1}(1-t)^{\beta-1} d t$

for the upper and lower fracture surfaces. Included in the figures are the values at different percentiles for the upper (up) and lower (low) fracture surfaces. The median value of $d_{\mathrm{c}, \max }$ for all 2071 fractures (including uncoated surfaces) is $0.1 \mathrm{~mm}$, while the arithmetic mean is $0.14 \mathrm{~mm}$. For at least $99 \%$ of the fracture surfaces, the fracture coating thickness is less than $1 \mathrm{~mm}$. The corresponding median value of $d_{\mathrm{c}}$ is only $0.02 \mathrm{~mm}$, while the arithmetic mean is $0.06 \mathrm{~mm}$. For $18 \%$ of the fractures investigated by Eklund and Mattsson (2009) both the upper and lower fracture surfaces were fresh and uncoated, while in $22 \%$ of the cases this applied to at least one fracture surface. This latter value is reflected in the lower tail of the CDF of Fig. 8. Fractures mapped as uncoated are discussed in detail in (Claesson Liljedahl et al. 2011).

\section{Discussion}

A main objective of this paper is to provide useful information on fracture mineral abundances for solute transport and hydrogeochemical modelling. A priority has been to reduce the extensive amount of mapping data into parameterised distributions and non-parametric data with constrained uncertainties; yet retaining the main characteristics of the sampled data. The measurement limit, in terms of $d_{\text {mean }}$ (Fig. 5) has improved much compared to the previous measurement limit of the layer thickness, which was $0.5 \mathrm{~mm}$. This has been crucial when analysing the data, as about $95 \%$ of the observed layer thicknesses are below $0.5 \mathrm{~mm}$ (Table 3 and Fig. 8). Lowering the measurements limit is a major achievement that greatly improved the accuracy in both the non-parametric and parametric analyses in this work. The new measurement limits, for both $d_{\text {mean }}$ and $C_{\text {vis }}$ manifest by truncations in the lower tails of the CDFs of Fig. 5 and Fig. 7. The truncations are, however, well below the parameters' mean values and the overlooked fracture mineral amounts and coverages are insignificant when modelling solute transport and the hydrogeochemical evolution.

The results show an extensive spread in both $C_{\text {vis }}$ and $d_{\text {mean }}$ for each fracture mineral. This can be interpreted as great variability between different fractures, within fracture planes or a combination of the two. As the borehole only samples a minor part of the fracture plane we cannot promote one interpretation over the other. Uncertainties may also contribute to the variability, especially those related to mixing of mineral layers and mineral identification. The variability between different sub-volumes of the rock is however limited, particularly for chlorite and pyrite. This strengthens the usability of flow path averaged mineral amounts and coverages when modelling solute transport over long distances. It also implies that heterogeneity must be recognised in models over short distances, where only one or a few connected fractures are concerned. This is often the case in small-scale tracer tests, for which applicable data may be found in the tails, or in the centre, of our delivered distributions. For calcite, the
Table 5 Parameterisation for $d_{\text {mean }}\left(\log\right.$-normal), $C_{\text {vis }}$ (truncated log-normal), and $C_{\mathrm{vis}}$ (beta) distributions of all Forsmark data

\begin{tabular}{llll}
\hline & $\log _{\mathbf{1 0}}\left(\boldsymbol{d}_{\text {mean }} \mathbf{m m}\right)(\boldsymbol{\mu} ; \sigma)$ & $\log _{\mathbf{1 0}}\left(\boldsymbol{C}_{\mathrm{vis}} \boldsymbol{\%}\right)(\boldsymbol{\mu} ; \sigma)$ & $\boldsymbol{C}_{\text {vis }}\left(\mathrm{m}^{\mathbf{2}} / \mathbf{m}^{\mathbf{2}}\right)(\boldsymbol{\alpha} ; \boldsymbol{\beta})$ \\
\hline Calcite & $-1.47 ; 0.70$ & $0.84 ; 0.64$ & $0.33 ; 1.55$ \\
Chlorite & $-0.93 ; 0.46$ & $1.37 ; 0.49$ & $0.66 ; 1.09$ \\
Pyrite & $-4.01 ; 1.26$ & $-1.52 ; 1.18$ & $0.18 ; 39.0$ \\
\hline
\end{tabular}




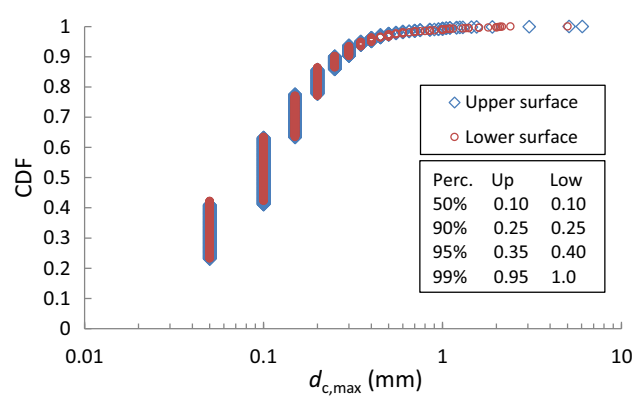

Fig. 8 Cumulative distribution functions of fracture coating thicknesses for the upper and lower fracture surface for all 2071 mapped fractures in Forsmark. The fraction of uncoated fractures can be deduced from the

populations in different rock sub-volumes had a weaker relation, which may be related to the complexity of calcite's paragenetic sequence. If interactions with calcite are attributed high importance, the radionuclide transport models may need to be segmented on different rock volumes, even for longer flow paths, if the demand on resolution is particularly high.

For the purpose of illustrating the possible use of our results in subsequent modelling, non-parametric data for $d_{\text {mean }}$ and $C_{\text {vis }}$ of chlorite are used in a deterministic calculation example below. We have kept the example as simple as possible, as it is outside the scope of this article to advice on how to properly incorporate the data in more advanced models. Often such advanced models are tailored to the particular problem and it falls upon the modeller to choose the format of the used input data.

Consider an arbitrary flow path in the Forsmark host rock from the proposed repository at $500 \mathrm{~m}$ depth to ground surface, with a total length $L$ of $1 \mathrm{~km}$ and an average width $W$ of $0.3 \mathrm{~m}$. Water flowing along this flow path may interact with a certain amount of chlorite present as fracture mineral. On average at the Forsmark site, approximately $24 \%$ of the open fractures contain chlorite in quantifiable amounts. This can be seen from Table 2, where $505\left(n_{\text {quant }}\right)$ of in total $2071\left(n_{\text {tot }}\right)$ mapped fractures held quantitative amounts of chlorite. These fractures have on average a chlorite mineral thickness $d_{\text {mean }}$ of $0.216 \mathrm{~mm}$ (Table 3 ). Disregarding the amount of chlorite that could only be qualitatively noted, the chlorite volume $V_{\mathrm{chl}}\left(\mathrm{m}^{3}\right)$ expected to be present along this flow path is approximately:

$$
\begin{aligned}
V_{\text {chl }} & =L \cdot W \cdot \frac{n_{\text {quant }}}{n_{\text {tot }}} \cdot d_{\text {mean }}=1000 \mathrm{~m} \cdot 0.3 \mathrm{~m} \cdot \frac{505}{2071} \cdot 0.216 \cdot 10^{-3} \mathrm{~m} \\
& =0.016 \mathrm{~m}^{3}
\end{aligned}
$$

Based on reported chlorite densities varying in the range 2.6 to $3.3 \mathrm{~g} \mathrm{~cm}^{-3}$ (Reynolds 1989), between 41 and $52 \mathrm{~kg}$ of chlorite would be present as fracture mineral along the flow path. The internal surface area of $50 \mathrm{~kg}$ of chlorite would be in the range of 25,000 to $250,000 \mathrm{~m}^{2}$, as the specific surface area of chlorite is roughly $0.5-5 \mathrm{~m}^{2} / \mathrm{g}$ (Zazzi 2009). Neglecting the internal surface area and any surface roughness of the minerals, the

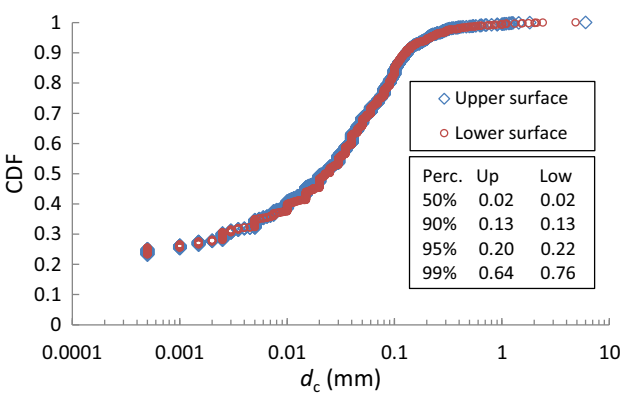

lowest percentiles for the shown data $(\sim 22 \%)$. The included tables show $d_{\mathrm{c}, \max }$ and $d_{\mathrm{c}}$ at different percentiles in millimetres. Spot minerals are not accounted for in this exercise

macroscopic surface area of chlorite $A_{\mathrm{chl}}\left(\mathrm{m}^{2}\right)$, directly exposed to flowing water along the flow path, would be:

$$
\begin{aligned}
A_{\text {chl }} & =L \cdot W \cdot \frac{n_{\text {quant }}}{n_{\text {tot }}} \cdot 2 \cdot C_{\text {vis }} \\
& =1000 \mathrm{~m} \cdot 0.3 \mathrm{~m} \cdot \frac{505}{2071} \cdot 2 \cdot 0.378=55 \mathrm{~m}^{2}
\end{aligned}
$$

where $C_{\text {vis }}=37.8 \%$ is taken from the arithmetic mean shown in Table 3.

In this article we have intentionally focused on similarities between different sub-volumes. This is partly as the degree of resolution needed for large-scale solute transport modelling is relatively low, due to the usage of flow path averaged values, and partly as the statistical analysis supported this. It is recognised that more detailed investigations of the observed differences are required for other applications and fields of interests, e.g. palaeohydrogeology.

\section{Conclusions}

This entire campaign started by identifying the lack of quantitative data on fracture mineral amounts, which are needed for long-term radionuclide transport and hydrogeochemical evolution modelling. To rectify this, a mapping methodology was developed; extensive mapping was performed; and the results were statistically analysed. This has given an unprecedented knowledge of fracture mineral amounts at the Forsmark and Laxemar sites. Major conclusions are, in relation to our sitespecific knowledge prior to this campaign: 1) The fracture minerals exist in quite small amounts. They thereby offer a smaller volume of sorption and reaction material than previously believed. 2) The fracture minerals do not always cover the entire fracture surface, but are often patch wise distributed. 3) The thickness of the fracture coatings is on average very small. While our previous perception of the fracture coating thickness was in the millimetre range, we have shown that fracture coatings on average are at least ten times thinner. This suggests a limited long-term impact of fracture coatings 
on retardation and solute exchange by matrix diffusion between flow paths and the rock matrix. The small amounts of fracture minerals also point to the importance of minerals in the rock matrix, which may be accessed by matrix diffusion, for the groundwater chemistry stability. 4) Based on statistical data, the fracture mineral amounts in different rock volumes do not differ to a degree that, on its own, generally calls for radionuclide transport models that is segmented on different rock volumes. Unless having very high demands on resolution, the same flow path averaged values can be used for all modelled flow paths.

Acknowledgments The authors would like to acknowledge the Swedish Nuclear Fuel and Waste Management Company for funding and, in particular, Anders Ström, Jan-Olof Selroos, Björn Gylling and Ignasi Puigdomenech for technical support. We would also like to acknowledge Prof. Ivars Neretnieks, Jordi Bruno, Isabelle Olofsson, Allan Stråhle, Eva-Lena Tullborg, Björn Sandström and Henrik Drake for their valuable technical support. Acknowledged last but not least are the drill core mapping teams lead by Stefan Eklund and Karl-Johan Mattson whose extensive sampling work forms the basis for the evaluation in this article.

Open Access This article is distributed under the terms of the Creative Commons Attribution 4.0 International License (http:// creativecommons.org/licenses/by/4.0/), which permits unrestricted use, distribution, and reproduction in any medium, provided you give appropriate credit to the original author(s) and the source, provide a link to the Creative Commons license, and indicate if changes were made.

\section{References}

Andersson J, Skagius K, Winberg A, Lindborg T, Ström A (2013) Sitedescriptive modelling for a final repository for spent nuclear fuel in Sweden. Environ Earth Sci 69:1045-1060. doi:10.1007/s12665013-2226-1

Andersson P, Byegård J, Tullborg E-L, Doe T, Hermanson J, Winberg A (2004) In situ tracer tests to determine retention properties of a block scale fracture network in granitic rock at the Äspö Hard Rock Laboratory, Sweden. J Contam Hydrol 70:271-297. doi:10.1016/j. jconhyd.2003.09.009

Auqué L, Gimeno MJ, Gómez J, Nilsson A-C (2008) Potentiometrically measured $\mathrm{Eh}$ in groundwaters from the Scandinavian shield. Appl Geochem 23:1820-1833. doi:10.1016/j.apgeochem.2008.02.016

Birgersson L, Neretnieks I (1990) Diffusion in the matrix of granitic Rock: Field test in the stripa mine. Water Resour Res 26:28332842. doi:10.1029/WR026i011p02833

Byegård J, Selnert E, Tullborg E-L (2008) Bedrock transport properties. Data evaluation and retardation model. Site descriptive modelling SDM-Site Forsmark, SKB R-08-98. Svensk Kärnbränslehantering $\mathrm{AB}$, Stockholm

Crawford J (2010) Bedrock Kd data and uncertainty assessment for application in SR-Site geosphere transport calculations., SKB R-1048. Svensk Kärnbränslehantering AB, Stockholm

Drake H, Tullborg E-L (2009) Fracture mineralogy Laxemar. Site descriptive modelling SDM-Site Laxemar, SKB R-08-99. Svensk Kärnbränslehantering $\mathrm{AB}$, Stockholm

Drake H, Tullborg E-L, MacKenzie AB (2009a) Detecting the nearsurface redox front in crystalline bedrock using fracture mineral distribution, geochemistry and U-series disequilibrium. Appl Geochem 24:1023-1039. doi:10.1016/j.apgeochem.2009.03.004

Drake H, Tullborg E-L, Page L (2009b) Distinguished multiple events of fracture mineralisation related to far-field orogenic effects in Paleoproterozoic crystalline rocks, simpevarp area, SE Sweden. Lithos 110:37-49. doi:10.1016/j.lithos.2008.12.003

Eklund S, Mattsson K-J (2009) Quantitative mapping of fracture minerals in Forsmark. Forsmark site investigation, SKB P-08-47. Svensk Kärnbränslehantering $\mathrm{AB}$, Stockholm

Eklund S, Mattsson K-J (2008) Quantitative mapping of fracture minerals in Laxemar. Oskarshamn site investigation, SKB P-08-38. Svensk Kärnbränslehantering $\mathrm{AB}$, Stockholm

Follin S, Levén J, Hartley L, Jackson P, Joyce S, Roberts D, Swift B (2007) Hydrogeological characterisation and modelling of deformation zones and fracture domains, Forsmark modelling stage 2.2, SKB R-07-48. Svensk Kärnbränslehantering AB, Stockholm

Follin S, Stephens MB, Laaksoharju M, Nilsson A-C, Smellie JAT, Tullborg E-L (2008) Modelling the evolution of hydrochemical conditions in the fennoscandian shield during Holocene time using multidisciplinary information. Appl Geochem 23:2004-2020. doi:10. 1016/j.apgeochem.2008.02.022

Gilkes RJ, Suddhiprakarn A, Armitage TM (1980) Scanning electron microscope morphology of deeply weathered granite. Clay Clay Miner 28:29-34. doi:10.1346/CCMN.1980. 0280104

Hermansson T, Stephens MB, Corfu F, Andersson J, Page L (2007) Penetrative ductile deformation and amphibolite-facies metamorphism prior to $1851 \mathrm{Ma}$ in the western part of the svecofennian orogen, fennoscandian shield. Precambrian Res 153:29-45. doi:10. 1016/j.precamres.2006.11.009

Johnson RA (1994) Miller and Freund's probability and statistics for engineers, 5th edn Prentice Hall International

Kruskal WH, Wallis WA (1952) Use of ranks in one-criterion variance analysis. J Am Stat Assoc 47:583-621. doi:10.1080/01621459. 1952.10483441

Laaksoharju M, Gascoyne M, Gurban I (2008a) Understanding groundwater chemistry using mixing models. Appl Geochem 23:19211940. doi:10.1016/j.apgeochem.2008.02.018

Laaksoharju M, Smellie J, Tullborg E-L, Gimeno M, Molinero J, Gurban I, Hallbeck L (2008b) Hydrogeochemical evaluation and modelling performed within the Swedish site investigation programme. Appl Geochem 23:1761-1795. doi:10.1016/ j.apgeochem.2008.02.015

Claesson Liljedahl L, Munier R, Sandström B, Drake H, Tullborg E-L (2011) Assessment of fractures classified as non-mineralised in the sicada database, SKB R-11-02. Svensk Kärnbränslehantering AB, Stockholm

Ludvigson J-E, Hansson K, Rouhiainen P (2002) Methodology study of posiva difference flow meter in borehole KLX02 at laxemar, SKB R-01-52. Svensk Kärnbränslehantering AB, Stockholm

Luukkonen A, Pitkänen P, Partamies S (2004) Significance and estimations of lifetime of natural fracture mineral buffers in the olkiluoto bedrock, posiva working report 2004-08. Posiva OY

Löfgren M, Sidborn M (2010a) Statistical analysis of results from the quantitative mapping of fracture minerals in Forsmark. Site descriptive modelling - complementary studies, SKB R-09-30. Svensk Kärnbränslehantering, $\mathrm{AB}$, Stockholm

Löfgren M, Sidborn M (2010b) Statistical analysis of results from the quantitative mapping of fracture minerals in Laxemar. Site descriptive modelling - complementary studies, SKB R-09-31. Svensk Kärnbränslehantering, $\mathrm{AB}$, Stockholm

Miller W, Alexander R, Chapman N, et al. (eds) (1994) Natural analogue studies in the geological disposal of radioactive wastes. Studies in Environmental Science. Elsevier B. V, In, pp. 1-395 
Neretnieks I (1980) Diffusion in the rock matrix: An important factor in radionuclide retardation? J Geophys Res 85:4379-4397. doi:10. 1029/JB085iB08p04379

NIST (2012) NIST/SEMANTECH E-Handbook of Statistical Methods http://www.itl.nist.gov/div898/handbook/. Accessed 20 Dec 2012

Ota K, Möri A, Alexander WR, Frieg B, Schild M (2003) Influence of the mode of matrix porosity determination on matrix diffusion calculations. J Contam Hydrol 61:131-145. doi:10.1016/S0169-7722(02) 00139-0

Petersson J, Skogsmo G, von Dalwigk I, Wängnerud A, Berglund J (2006) Boremap mapping of telescopic drilled borehole KFM01D. Forsmark site investigation, SKB P-06-132. Svensk Kärnbränslehantering $\mathrm{AB}$, Stockholm

POSIVA (2012) Safety case for the disposal of spent nuclear fuel at olkiluoto - performance assessment 2012, posiva report 2012-04. Posiva OY

RETROCK (2005) Treatment of radionuclide transport in geosphere within safety assessments. Final report of the RETROCK Concerted Action, EUR 21230. European Commission

Reynolds RC (1989) Principles and techniques of quantitative analysis of clay minerals by X-ray powder diffraction. In: Pevear DR, Mumpton FA (eds) Quantitative Mineral Analysis of Clays. The Clay Mineral Society. Evergreen, Colorado pp 4-36

Sandström B, Annersten H, Tullborg E-L (2010) Fracture-related hydrothermal alteration of metagranitic rock and associated changes in mineralogy, geochemistry and degree of oxidation: a case study at forsmark, Central Sweden. Int J Earth Sci 99:1-25. doi:10.1007/ s00531-008-0369-1

Sandström B, Tullborg E-L (2009) Episodic fluid migration in the fennoscandian shield recorded by stable isotopes, rare earth elements and fluid inclusions in fracture minerals at forsmark, Sweden. Chem Geol 266:126-142. doi:10.1016/j.chemgeo.2009. 04.019

Sandström B, Tullborg E-L, Page L (2008a) Fracture mineralogy and $40 \mathrm{Ar} / 39 \mathrm{Ar}$ ages of adularia in fracture filling and $\mathrm{K}$-feldspar in breccia. Data from drill cores KFM01C, KFM01D, KFM02B, KFM04A, KFM06A, KFM06B, KFM07A, KFM08A, KFM08B, KFM08C, KFM08D, KFM09A, KFM09B, KFM10A and KFM11A. Forsmark site investigation, SKB P-08-14. Svensk Kärnbränslehantering $\mathrm{AB}$

Sandström B, Tullborg E-L, Smellie J, MacKenzie AB, Suksi J (2008b) Fracture mineralogy of the forsmark site SDM-site forsmark, SKB R-08-102. Svensk Kärnbränslehantering AB, Stockholm

Sandström B, Tullborg E-L (2005) Forsmark site investigation. Fracture mineralogy. Results from fracture minerals and wall rock alteration in KFM01B, KFM04A, KFM05A and KFM06A. SKB P-05-197, Svensk Kärnbränslehantering $\mathrm{AB}$

Selroos J-O, Follin S (2010) SR-site groundwater flow modelling methodology, setup and results, SKB R-09-22. Svensk Kärnbränslehantering $\mathrm{AB}$, Stockholm

Shapiro SS, Wilk MB (1965) An analysis of variance test for normality (complete samples). Biometrika 52:591-611. doi:10.1093/biomet/ 52.3-4.591

Shirvani M, Shariatmadari H, Kalbasi M, Nourbakhsh F, Najafi B (2006) Sorption of cadmium on palygorskite, sepiolite and calcite: equilibria and organic ligand affected kinetics. Colloids Surf A Physicochem Eng Asp 287:182-190. doi:10.1016/j.colsurfa.2006. 03.052

Sidborn M, Sandström B, Tullborg E-L, Salas J, Maia F, Delos A, Molinero J, Hallbeck L, Pedersen K (2010) SR-site: oxygen ingress in the rock at forsmark during a glacial cycle, SKB TR-10-57. Svensk Kärnbränslehantering $\mathrm{AB}$, Stockholm

Siitari-Kauppi M, Marcos N, Klobes P, Goebbels J, Timonen J, Hellmuth K-H (2003) Physical rock matrix characteriszation. The Palmottu Natural Analogue Project, YST-118. Geological Survey of Finland
SKB (2011) Long-term safety for the final repository for spent nuclear fuel at Forsmark. Main report of the SR-Site project, SKB TR-1101. Svensk Kärnbränslehantering $\mathrm{AB}$, Stockholm

SKB (2008a) Site description of Forsmark at completion of the site investigation phase. SDM-Site Forsmark, SKB TR-08-05. Svensk Kärnbränslehantering $\mathrm{AB}$, Stockholm

SKB (2010) Comparative analysis of safety related site characteristics, SKB TR-10-54. Svensk Kärnbränslehantering AB, Stockholm

SKB (2015) Safety analysis for SFR Long-Term safety main report for the safety assessment SR-PSU, revised edition, TR-14-01. Svensk Kärnbränslehantering $\mathrm{AB}$, Stockholm

Snecdecor GW, Cochran WG (1991) Statistical methods, 8th edn. John Wiley \& Sons

Sokolnicki M, Heikkinen P (2008) Difference flow measurements in outokumpu deep hole OKUR2500, posiva working report 200887. Posiva OY

Spiessl S, Mayer K, MacQuarrie K (2009) Reactive transport modelling in fractured rock-redox stability study, NWMO TR-2009-04. Nuclear Waste Management Organization, Toronto

Stephens M, Fox A, La Pointe P, Simeonov A, Isaksson H, Hermanson J, Öhman J (2007) Geology Forsmark. Site descriptive modelling Forsmark stage 2.2, SKB R-07-45. Svensk Kärnbränslehantering $\mathrm{AB}$, Stockholm

Stephens MB (2010) Bedrock geology - overview and excursion guide. Forsmark site investigation, SKB R-10-04. Svensk Kärnbränslehantering $\mathrm{AB}$, Stockholm

Ström A, Andersson J, Skagius K, Winberg A (2008) Site descriptive modelling during characterization for a geological repository for nuclear waste in Sweden. Appl Geochem 23:1747-1760. doi:10. 1016/j.apgeochem.2008.02.014

Terry RD, Chilingar GV (1955) Summary of "Concerning some additional aids in studying sedimentary formations," by M. S Shvetsov J Sediment Res 25 :229-234.

Tullborg E-L, Drake H, Sandström B (2008) Palaeohydrogeology: A methodology based on fracture mineral studies. Appl Geochem 23:1881-1897. doi:10.1016/j.apgeochem.2008.02.009

Wels C, Smith L (1994) Retardation of sorbing solutes in fractured media. Water Resour Res 30:2547. doi:10.1029/94WR01128

Widestrand H, Byegård J, Cvetkovic V, Tullborg E-L, Winberg A, Andersson P, Siitari-Kauppi M (2007) Sorbing tracer experiments in a crystalline rock fracture at Äspö (Sweden): 1. experimental setup and microscale characterization of retention properties. Water Resour Res 43:W10413. doi:10.1029/2006WR005277

Widler AM, Seward TM (2002) The adsorption of gold(I) hydrosulphide complexes by iron sulphide surfaces. Geochim Cosmochim Acta 66:383-402. doi:10.1016/S0016-7037(01)00791-8

Vidstrand P, Follin S, Zugec N (2010) Groundwater flow modelling of periods with periglacial and glacial climate conditions - forsmark, SKB R-09-21. Svensk Kärnbränslehantering AB, Stockholm

Väisäsvaara J, Leppänen H, Pekkanen J (2006) Difference flow logging in borehole KFM01D. Forsmark site investigation, SKB P-06-161. Svensk Kärnbränslehantering $\mathrm{AB}$, Stockholm

Zachara JM, Cowan CE, Resch CT (1993) Metal cation/anion adsorption on calcium carbonate: implications to metal ion concentrations in groundwater. In: Allen HE, Perdue EM, Brown DS (eds) Metals in groundwater. Lewis Publishers, Boca Raton

Zazzi Å (2009) Chlorite: geochemical properties, dissolution kinetics and $\mathrm{Ni}(\mathrm{II})$ sorption. Doctoral Thesis in Chemistry, Chemical Science and Engineering, Royal Institute of Technology, Stockholm, Sweden

Zhang C (2007) Fundamentals of environmental sampling and analysis. John Wiley \& Sons

Zhou Q, Liu H-H, Molz FJ, Zhang Y, Bodvarsson GS (2007) Field-scale effective matrix diffusion coefficient for fractured rock: results from literature survey. J Contam Hydrol 93:161-187. doi:10.1016/j. jconhyd.2007.02.002 